\title{
Impact of molecular structure on secondary organic aerosol formation from aromatic hydrocarbon photooxidation under low-NO $x$ conditions
}

\author{
Lijie Li $^{1,2}$, Ping Tang ${ }^{1,2}$, Shunsuke Nakao ${ }^{1,2, a}$, and David R. Cocker III ${ }^{1,2}$ \\ ${ }^{1}$ University of California, Riverside, Department of Chemical and Environmental Engineering, Riverside, CA 92507, USA \\ ${ }^{2}$ College of Engineering - Center for Environmental Research and Technology (CE-CERT), Riverside, CA 92507, USA \\ ${ }^{a}$ currently at: Clarkson University, Department of Chemical and Biomolecular Engineering, Potsdam, NY 13699, USA
}

Correspondence to: David R. Cocker III (dcocker@engr.ucr.edu)

Received: 24 October 2015 - Published in Atmos. Chem. Phys. Discuss.: 15 January 2016

Revised: 13 July 2016 - Accepted: 28 July 2016 - Published: 31 August 2016

\begin{abstract}
The molecular structure of volatile organic compounds determines their oxidation pathway, directly impacting secondary organic aerosol (SOA) formation. This study comprehensively investigates the impact of molecular structure on SOA formation from the photooxidation of 12 different eight- to nine-carbon aromatic hydrocarbons under low- $\mathrm{NO}_{x}$ conditions. The effects of the alkyl substitute number, location, carbon chain length and branching structure on the photooxidation of aromatic hydrocarbons are demonstrated by analyzing SOA yield, chemical composition and physical properties. Aromatic hydrocarbons, categorized into five groups, show a yield order of ortho (o-xylene and $o$-ethyltoluene) $>$ one substitute (ethylbenzene, propylbenzene and isopropylbenzene) $>$ meta $(m$-xylene and $m$ ethyltoluene) $>$ three substitute (trimethylbenzenes) $>$ para ( $p$-xylene and $p$-ethyltoluene). SOA yields of aromatic hydrocarbon photooxidation do not monotonically decrease when increasing alkyl substitute number. The ortho position promotes SOA formation while the para position suppresses aromatic oxidation and SOA formation. Observed SOA chemical composition and volatility confirm that higher yield is associated with further oxidation. SOA chemical composition also suggests that aromatic oxidation increases with increasing alkyl substitute chain length and branching structure. Further, carbon dilution conjecture developed by Li et al. (2016) is extended in this study to serve as a standard method to determine the extent of oxidation of an alkylsubstituted aromatic hydrocarbon.
\end{abstract}

\section{Introduction}

Organic aerosols are critical to human health (Dockery et al., 1993; Krewski et al., 2003; Davidson et al., 2005), climate change (IPCC, 2007) and visibility (Pöschl, 2005; Seinfeld and Pandis, 2006). Global anthropogenic secondary organic aerosol (SOA) sources are underestimated by current models (Henze et al., 2008; Matsui et al., 2009; Hallquist et al., 2009; Farina et al., 2010) and are more likely to increase due to the increase of known anthropogenic emissions (Heald et al., 2008). Therefore, it is crucial to explore SOA formation mechanisms from anthropogenic precursors.

Aromatic hydrocarbons are major anthropogenic SOA precursors (Kanakidou et al., 2005; Henze et al., 2008; Derwent et al., 2010). $C_{8}$ (ethylbenzene, xylenes) and $C_{9}$ (ethyltoluenes and trimethylbenzenes) aromatics are important aromatic hydrocarbons in the atmosphere besides toluene and benzene (Monod et al., 2001; Millet et al., 2005; Heald et al., 2008; Kansal, 2009; Hu et al., 2015). The major sources of $\mathrm{C}_{8}$ and $\mathrm{C}_{9}$ aromatic hydrocarbons are fuel evaporation (Kaiser et al., 1992; Rubin et al., 2006; Miracolo et al., 2012), tailpipe exhaust (Singh et al., 1985; Monod et al., 2001; Lough et al., 2005; Na et al., 2005; Correa and Arbilla, 2006) and solvent use (Zhang et al., 2013). $\mathrm{C}_{8}$ aromatic hydrocarbons (ethylbenzene and xylenes (ortho, meta and para) are categorized as hazardous air pollutants under the US Clean Air Act Amendments of 1990; http://www.epa.gov/ttnatw01/ orig189.html). Toluene and $\mathrm{C}_{8}$ aromatics dominate the anthropogenic SOA precursors and SOA yield from all $\mathrm{C}_{9}$ aromatics is currently predicted to be equal to that of toluene 
(Bahreini et al., 2009). The chemical composition of aromatic SOA remains poorly understood with less than $50 \%$ of aromatic hydrocarbon photooxidation products identified (Forstner et al., 1997; Fisseha et al., 2004; Hamilton et al., 2005; Sato et al., 2007). Aromatic hydrocarbon photooxidation mechanisms remain uncertain except for the initial step ( $\sim 90 \%$ OH-addition reaction) (Calvert et al., 2002). Hence, understanding the atmospheric reaction mechanisms of $\mathrm{C}_{8}$ and $\mathrm{C}_{9}$ aromatic hydrocarbons and properly quantifying their SOA formation potential presents unique challenges due to the variety in their molecular structure and the electron density of the aromatic ring.

Volatile organic compound (VOC) structure impacts the gas-phase reaction mechanism (Ziemman and Atkinson, 2012) and kinetic reaction rate (eg. $k_{\mathrm{OH}}$; Atkinson, 1987), thereby influencing the resulting SOA properties and mass yield. Molecular structure impacts on SOA formation from alkanes have been previously studied (Lim and Ziemann, 2009; Ziemann, 2011; Lambe et al., 2012; Tkacik et al., 2012; Yee et al., 2013; Loza et al., 2014). It is generally observed that SOA yield decreases from cyclic alkanes to linear alkanes and to branched alkanes. The relative location of the methyl group on the carbon chain also affects SOA yield (Tkacik et al., 2012). It is further found that the SOA yield and structure relationship is influenced by $\mathrm{C}=\mathrm{C}$ groups (Ziemann, 2011). Understanding the SOA yield and structure relationship of aromatic compounds in a similar way is necessary due to the atmospheric importance of aromatic hydrocarbons.

Previously, aromatic studies categorized SOA yield solely based on substitute number (Odum et al., 1997a, b). However, those chamber experiments were conducted at high$\mathrm{NO}_{x}$ conditions, which are well above levels present in the atmosphere. Song et al. $(2005,2007)$ found that initial $\mathrm{HC} / \mathrm{NO}_{x}$ ratios (HC being hydrocarbon) significantly impact SOA yields during aromatic photooxidation with yields increasing as $\mathrm{NO}_{x}$ levels decreased. $\mathrm{Ng}$ et al. (2007) show there is no significant yield difference between one-substitute (toluene) and two-substitute ( $m$-xylene) aromatics in the absence of $\mathrm{NO}_{x}$. The current work focuses on molecular structure impact on SOA formation at more atmospherically relevant $\mathrm{NO}_{x}$ and aerosol loadings. $\mathrm{Li}$ et al. (2016) demonstrated the methyl-group-number impact on SOA formation under low- $\mathrm{NO}_{x}$ conditions. Also, aromatic compounds with para-position alkyl groups have been observed to form less SOA under various $\mathrm{NO}_{x}$ conditions than their isomers in previous studies. Izumi and Fukuyama (1990) found that $p$ xylene, $p$-ethyltoluene and 1,2,4-trimethylbenzene have low SOA formation potential under high- $\mathrm{NO}_{x}$ conditions. Song et al. (2007) observed that $p$-xylene has the smallest SOA yield among all xylenes in the presence of $\mathrm{NO}_{x}$. The relative methyl position to - $\mathrm{OH}$ in dimethyl phenols also impacts SOA yield in the absence of $\mathrm{NO}_{x}$ (Nakao et al., 2011), while Song et al. (2007) observed no significant SOA yield difference between $o$-xylene and $p$-xylene under $\mathrm{NO}_{x}$-free conditions. Moreover, previous studies mainly focused on the carbon number effect on SOA formation (Lim and Ziemann, 2009; Li et al., 2016) and seldom addressed the substitute carbon length impact on VOC oxidation and hence SOA formation. Different percentages of similar compounds are found when the substitute carbon length on the aromatic ring changes (Forstner et al., 1997; Huang et al., 2007, 2011). For example, a lower percentage of 3-methyl-2,5-furanone is observed in toluene than that of 3-ethyl-2,5-furanone in ethylbenzene (Forstner et al., 1997). Further, the branching structure on the aromatic substitute might impact the reaction pathway. It is possible that fragmentation is more favored on branched substitute alkoxy radicals than $n$-alkane substituents similar to alkanes (Atkinson and Arey, 2003).

Few studies comprehensively consider the overall alkyl effect on SOA formation from aromatic hydrocarbons, including the substitute number, position, carbon chain length and branching structure, especially under low- $\mathrm{NO}_{x}$ conditions. It is valuable to understand the relationship between aromatic hydrocarbon molecular structures and SOA physical and chemical characteristics. The effects of $\mathrm{OH}$ exposure (Lambe et al., 2012, 2015), mass loading (Shilling et al., 2009, $\alpha$-pinene; Pfaffenberger et al., 2013, $\alpha$-pinene) and NO condition ( $\mathrm{Ng}$ et al., 2007; Eddingsaas et al., 2012, $\alpha$-pinene) on SOA physical and chemical characteristics are previously discussed. However, few studies address the molecular structure effect of the precursor on SOA chemical composition, especially under atmospherically relevant conditions. Sato et al. (2012) show the chemical composition difference between ethylbenzene, $m$-xylene, $o$-xylene, 1,2,4trimethylbenzene and 1,3,5-trimethylbenzene under high absolute $\mathrm{NO}_{x}$ conditions and hypothesize that ketones prevent further oxidation during aromatic photooxidation compared with aldehydes. The SOA products detected in Sato's study are mainly small volatile compounds which are less likely to partition into the particle phase (Chhabra et al., 2011). Therefore, the study of Sato et al. (2012) indicates that further oxidation or oligomerization might contribute to SOA formation during aromatic photooxidation. Less SOA characterization data on propylbenzene and ethyltoluene compared with trimethylbenzene are available. However, Bahreini et al. (2009) suggest that the sum of the propylbenzene and ethyltoluene is on average a factor of 4-10 more abundant than trimethylbenzene.

This work examines 12 aromatic hydrocarbons, all of which are isomers with eight or nine carbons, to investigate the impact of molecular structure on SOA formation from aromatic hydrocarbon photooxidation under low $\mathrm{NO}_{x}(10-$ $138 \mathrm{ppb}$ ). Here, we investigate the substitute number, substitute position, alkyl carbon chain length and alkyl branching impacts on aromatic hydrocarbon oxidation. The effects of molecular structure impact on SOA yield, chemical composition ( $\mathrm{H} / \mathrm{C}, \mathrm{O} / \mathrm{C}, \mathrm{OS}_{\mathrm{c}}, f_{44}, f_{43}, f_{57}$ and $\left.f_{71}\right)$ and physical properties (density and VFR) are demonstrated. Alkyl sub- 
stitute dilution conjecture is further developed from methyl dilution theory ( $\mathrm{Li}$ et al., 2016).

\section{Method}

\subsection{Environmental chamber}

The UC Riverside/CE-CERT indoor dual $90 \mathrm{~m}^{3}$ environmental chambers were used in this study and are described in detail elsewhere (Carter et al., 2005). Experiments were all conducted at dry conditions $(\mathrm{RH}<0.1 \%)$, in the absence of inorganic seed aerosol and with temperature controlled to $27 \pm 1^{\circ} \mathrm{C}$. Seeded experiments to minimize wall effects have also been conducted in our chamber experiment with no measurable difference observed between the seeded and nonseeded experiment. Two movable top frames were slowly lowered during each experiment to maintain a slight positive differential pressure $\left(\sim 0.02^{\prime \prime} \mathrm{H}_{2} \mathrm{O}\right)$ between the reactors and enclosure to minimize dilution and/or contamination of the reactors. Additionally, 272115 W Sylvania 350BL blacklights are used as light sources for photooxidation.

A known volume of high-purity liquid hydrocarbon precursors from Sigma-Aldrich (ethylbenzene, 99.8\%; npropylbenzene, 99.8\%; isopropylbenzene, analytical standard; $m$-xylene, $99 \%$; $o$-xylene, $99 \% ; p$-xylene, $99 \% ; m$ ethyltoluene, $99 \%$; $o$-ethyltoluene, $99 \%$; $p$-ethyltoluene, $\geq 95 \%$; 1,2,3-trimethylbenzene, OEKANAL analytical standard; 1,2,4-trimethylbenzene, $98 \%$; 1,3,5-trimethylbenzene, analytical standard) was injected through a heated glass injection manifold system and flushed into the chamber with pure $\mathrm{N}_{2}$. NO was introduced by flushing pure $\mathrm{N}_{2}$ through a calibrated glass bulb filled to a predetermined partial pressure of pure NO. All hydrocarbons and NO are injected and well mixed before lights are turned on to start the experiment.

\subsection{Particle and gas measurement}

Particle size distribution between 27 and $686 \mathrm{~nm}$ was monitored by dual custom-built scanning mobility particle sizers (SMPS) (Cocker et al., 2001). Particle effective density was measured with an aerosol particle mass analyzer (APMSMPS) system (Malloy et al., 2009). Particle volatility was measured by a Dekati ${ }^{\circledR}$ thermodenuder volatility tandem differential mobility analyzer (VTDMA) (Rader and McMurry, 1986 ) with a $17 \mathrm{~s}$ heating zone residence time (Qi et al., 2010a). The heating zone was controlled to $100^{\circ} \mathrm{C}$ in this study with volume fraction remaining (VFR) calculated as $\left(D_{\mathrm{p}, \text { after TD }} / D_{\mathrm{p}} \text {, before, TD }\right)^{3}$.

Particle-phase chemical composition evolution was measured by a high-resolution time-of-flight aerosol mass spectrometer (HR-ToF-AMS; Aerodyne Research Inc.) (Canagaratna et al., 2007; DeCarlo et al., 2006). The sample was vaporized by a $600^{\circ} \mathrm{C}$ oven under vacuum, followed by a $70 \mathrm{eV}$ electron impact ionization. $f_{x}$ in this study is calculated as the mass fraction of the organic signal at $m / z=x$.
For example, $f_{44}, f_{43}, f_{57}$ and $f_{71}$ are the ratios of the organic signal at $m / z 44,43,57$ and 71 to the total organic signal, respectively (Chhabra et al., 2011; Duplissy et al., 2011). Elemental ratios for total organic mass, oxygen to carbon $(\mathrm{O} / \mathrm{C})$ and hydrogen to carbon $(\mathrm{H} / \mathrm{C})$ were determined using the elemental analysis technique (Aiken et al., 2007, 2008). Data were analyzed with ToF-AMS analysis toolkit Squirrel 1.56D/Pika 1.15D version. Evolution of SOA composition (Heald et al., 2010; Jimenez et al., 2009) refers to SOA chemical composition changes with time. $f_{44}$ and $f_{43+57+71}$ evolution and $\mathrm{H} / \mathrm{C}$ and $\mathrm{O} / \mathrm{C}$ evolution refer to the change of $f_{44}$ and $f_{43+57+71}$ with time and the change of $\mathrm{H} / \mathrm{C}$ and $\mathrm{O} / \mathrm{C}$ with time, respectively.

The Agilent 6890 gas chromatograph-flame ionization detector was used to measure aromatic hydrocarbon concentrations. A Thermal Environmental Instruments model 42C chemiluminescence $\mathrm{NO}$ analyzer was used to monitor $\mathrm{NO}$, $\mathrm{NO}_{y}-\mathrm{NO}$ and $\mathrm{NO}_{y}$. The gas-phase reaction model SAPRC11 developed by Carter and Heo (2013) was utilized to predict radical concentrations $\left(\cdot \mathrm{OH}, \mathrm{HO}_{2} \cdot \mathrm{RO}_{2} \cdot\right.$ and $\left.\mathrm{NO}_{3} \cdot\right)$.

\section{Result}

\subsection{SOA yield}

Photooxidation of $12 \mathrm{C}_{8}$ and $\mathrm{C}_{9}$ aromatic hydrocarbons was studied for low- $\mathrm{NO}_{x}$ conditions ( $\mathrm{HC} / \mathrm{NO}$ ratio 11.1$171 \mathrm{ppbC}: \mathrm{ppb})$. SOA yields for all aromatic hydrocarbons were calculated according to Odum et al. (1996) as the mass ratio of aerosol formed to parent hydrocarbon reacted. Experimental conditions and SOA yields are listed (Table 1) along with additional $m$-xylene, $o$-xylene, $p$ xylene and 1,2,4-trimethylbenzene experimental conditions from previous studies (Song et al., 2005, 2007; Li et al., 2016) (Table S2 in the Supplement). The uncertainty associated with 10 replicate $m$-xylene and NO experiments SOA yield is $<6.65 \%$. SOA yield as a function of particle mass concentration $\left(M_{o}\right)$, shown in Fig. 1, includes experiments listed in both Table 1 and Table S2. It is observed that both alkyl substitute number and position affect SOA yield. The SOA yield of two-substitute $\mathrm{C}_{8}$ and $\mathrm{C}_{9}$ aromatic hydrocarbons depends more on the substitute location than substitute length. This means that the yield trend of $o$-xylene is analogous to that of $o$-ethyltoluene. Similarly, the yield trends for meta- and para-position substituted $\mathrm{C}_{8}$ and $\mathrm{C}_{9}$ aromatic hydrocarbons will be analogous to each other. Ortho isomers ( $o$-xylene and $o$-ethyltoluene, marked as solid and hollow green circles, respectively) have the highest SOA yield for similar aerosol concentrations while para isomers ( $p$-xylene and $p$-ethyltoluene, marked as solid and hallow blue diamonds, respectively) have the lowest SOA yield level. Lower SOA yields for para isomers are consistent with previous observation by Izumi and Fukuyama (1990). Izumi and Fukuyama (1990) also sug- 
Table 1. Experiment conditions.

\begin{tabular}{|c|c|c|c|c|c|c|c|}
\hline Precursor & ID & $\begin{array}{r}\mathrm{HC} / \mathrm{NO} \\
\mathrm{ppbC}: \mathrm{ppb}\end{array}$ & $\begin{array}{l}\text { NO } \\
\mathrm{ppb}\end{array}$ & $\begin{array}{l}\mathrm{HC} \\
\mathrm{ppb}\end{array}$ & $\begin{array}{r}\Delta \mathrm{HC} \\
\mu \mathrm{g} \mathrm{m}^{-3}\end{array}$ & $\mu \mathrm{g} \mathrm{m}^{-3}$ & Yield \\
\hline \multirow[t]{7}{*}{ Ethylbenzene } & $1142 \mathrm{~A}$ & 17.0 & 47.4 & 101 & 331 & 22.0 & 0.066 \\
\hline & 1142B & 12.0 & 66.6 & 99.9 & 341 & 4.40 & 0.013 \\
\hline & $1146 \mathrm{~A}$ & 35.6 & 22.2 & 99.0 & 257 & 36.0 & 0.140 \\
\hline & 1146B & 23.0 & 34.8 & 100 & 331 & 23.6 & 0.071 \\
\hline & 1147B & 74.9 & 36.5 & 342 & 626 & 88.1 & 0.141 \\
\hline & $2084 \mathrm{~A}$ & 81.1 & 23.9 & 242 & 374 & 54.0 & 0.145 \\
\hline & 2084B & 93.8 & 20.3 & 238 & 266 & 44.3 & 0.167 \\
\hline \multirow[t]{2}{*}{ Propylbenzene } & $1245 \mathrm{~A}$ & 41.0 & 22.1 & 101 & 231 & 11.8 & 0.051 \\
\hline & $1246 \mathrm{~A}$ & 26.8 & 68.5 & 204 & 421 & 22.9 & 0.054 \\
\hline \multirow[t]{4}{*}{ Isopropylbenzene } & $1247 \mathrm{~A}$ & 40.3 & 22.4 & 100 & 301 & 33.2 & 0.110 \\
\hline & 1247B & 18.6 & 48.1 & 99.3 & 300 & 16.6 & 0.055 \\
\hline & $1253 \mathrm{~A}$ & 31.9 & 56.4 & 200. & 538 & 53.1 & 0.099 \\
\hline & $1253 B^{b}$ & 17.6 & 100 & 196 & 526 & 16.5 & 0.031 \\
\hline \multirow[t]{5}{*}{$o$-Xylene } & $1315 \mathrm{~A}$ & 13.2 & 49.8 & 82.2 & 324 & 26.3 & 0.081 \\
\hline & 1315B & 28.8 & 22.2 & 80.0 & 27 & 25.4 & 0.091 \\
\hline & $1320 \mathrm{~A}$ & 12.8 & 50.0 & 80.0 & 335 & 18.4 & 0.055 \\
\hline & $1321 \mathrm{~A}$ & 31.0 & 20.5 & 79.2 & 263 & 16.2 & 0.061 \\
\hline & 1321B & 61.3 & 10.4 & 80.0 & 226 & 9.80 & 0.044 \\
\hline \multirow[t]{2}{*}{$p$-Xylene } & $1308 \mathrm{~A}$ & 15.5 & 55.6 & 78.4 & 279 & 6.80 & 0.024 \\
\hline & 1308B & 171 & 22.9 & 78.8 & 274 & 11.3 & 0.041 \\
\hline \multirow[t]{9}{*}{$m$-Ethyltoluene } & $1151 \mathrm{~A}$ & 17.9 & 62.5 & 84.8 & 409 & 8.30 & 0.020 \\
\hline & 1151B & 31.0 & 32.3 & 86.4 & 415 & 28.7 & 0.069 \\
\hline & $1199 \mathrm{~A}$ & 8.8 & 45.4 & 100 & 447 & 72.0 & 0.161 \\
\hline & $1222 B$ & 41.7 & 69.4 & 100 & 484 & 70.9 & 0.146 \\
\hline & $1226 \mathrm{~B}$ & 11.3 & 137.6 & 201 & 895 & 138 & 0.154 \\
\hline & $1232 \mathrm{~A}$ & 27.5 & 122.0 & 200 & 901 & 150 & 0.167 \\
\hline & $1232 B$ & 33.1 & 67.5 & 194 & 751 & 117 & 0.155 \\
\hline & $1421 \mathrm{~A}$ & 41.0 & 22.1 & 97.9 & 409 & 46.2 & 0.112 \\
\hline & 1421B & 18.0 & 44.9 & 98.7 & 477 & 54.6 & 0.114 \\
\hline \multirow[t]{6}{*}{$o$-Ethyltoluene } & $1179 \mathrm{~A}$ & 16.3 & 52.9 & 91.7 & 399 & 86.5 & 0.216 \\
\hline & 1179B & 15.8 & 52.9 & 93.0 & 415 & 75.3 & 0.181 \\
\hline & $1202 \mathrm{~A}$ & 18.5 & 60.3 & 99.7 & 422 & 69.9 & 0.166 \\
\hline & $1215 \mathrm{~A}$ & 29.2 & 107 & 180 & 637 & 151 & 0.237 \\
\hline & $1413 \mathrm{~A}$ & 12.2 & 21.3 & 100 & 371 & 64.5 & 0.174 \\
\hline & 1413B & 24.1 & 45.8 & 98.4 & 455 & 64.4 & 0.141 \\
\hline \multirow[t]{6}{*}{$p$-Ethyltoluene } & $1194 \mathrm{~A}$ & 19.9 & 90.7 & 196 & 741 & 90.4 & 0.122 \\
\hline & 1194B & 13.0 & 88.4 & 200 & 761 & 73.0 & 0.096 \\
\hline & 1197A & 13.1 & 56.4 & 192 & 653 & 66.4 & 0.102 \\
\hline & 1197B & 14.8 & 98.5 & 192 & 710 & 58.4 & 0.082 \\
\hline & 1214B & 26.0 & 53.4 & 102 & 418 & 29.1 & 0.069 \\
\hline & $1601 \mathrm{~A}$ & 39.9 & 31.2 & 109 & 452 & 17.6 & 0.039 \\
\hline \multirow[t]{4}{*}{ 1,2,3-Trimethylbenzene } & $1158 \mathrm{~A}$ & 19.8 & 10.3 & 79.9 & 296 & 22.2 & 0.075 \\
\hline & $1158 \mathrm{~B}$ & 15.6 & 22.4 & 79.9 & 379 & 32.3 & 0.085 \\
\hline & $1162 \mathrm{~A}$ & 15.8 & 33.4 & 80.1 & 391 & 46.5 & 0.119 \\
\hline & 1162B & 14.9 & 40.0 & 80.4 & 399 & 46.6 & 0.117 \\
\hline \multirow[t]{5}{*}{ 1,3,5-Trimethylbenzene } & $1153 \mathrm{~A}$ & 65.2 & 11.0 & 79.5 & 309 & 12.4 & 0.040 \\
\hline & 1153B & 35.3 & 20.4 & 80.0 & 381 & 19.6 & 0.051 \\
\hline & $1156 \mathrm{~A}$ & 22.3 & 32.3 & 80.2 & 379 & 24.8 & 0.065 \\
\hline & $1156 \mathrm{~B}$ & 15.5 & 46.1 & 79.6 & 390 & 19.0 & 0.049 \\
\hline & 1329B & 11.1 & 64.8 & 80.0 & 296 & 3.00 & 0.007 \\
\hline
\end{tabular}

Note: ${ }^{\mathrm{a}} M_{O}$ is a wall-loss-and density-corrected particle mass concentration. ${ }^{\mathrm{b}}$ Not used in curve fitting. 


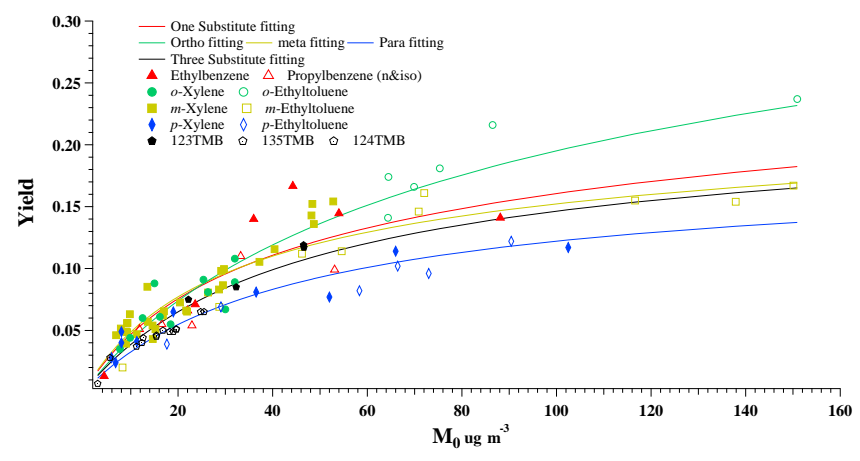

Figure 1. Aromatic SOA yields as a function of $M_{o}$. Note: Song et al. (2005, 2007) and Li et al. (2016) data are also included; 123TMB is 1,2,3-Trimethylbenzene; $135 \mathrm{TMB}$ is $1,3,5$-Trimethylbenzene; $124 \mathrm{TMB}$ is $1,2,4$-Trimethylbenzene.

gest that 1,2,4-trimethylbenzene yields are lower than for other aromatic hydrocarbons. The current study does not show a significant SOA yield difference between 1,2,4trimethylbenzene and 1,3,5-trimethylbenzene. It is difficult to compare 1,2,3-trimethylbenzene yields with the former two trimethylbenzenes since 1,2,3-trimethylbenzene mass loading is much higher than the former two.

Aromatic hydrocarbons having only one substitute (ethylbenzene, n-propylbenzene and isopropylbenzene) or three substitutes (1,2,3-trimethylbenzene, 1,2,4-trimethylbenzene and 1,3,5-trimethylbenzene) tend to have yields similar to the meta-position two-alkyl aromatics. Odum et al. (1997b) categorized SOA yield formation potential solely based on substitute number and stated that aromatics with less than two methyl or ethyl substitutes form more particulate matter than those with two or more methyl or ethyl substitutes on the aromatic ring. However, Odum's work was conducted for high- $\mathrm{NO}_{x}$ conditions and had insufficient data to compare isomer yield differences (e.g., only two low mass loadings for $o$-xylene data). The strong low-yield (two or more substitutes) and high-yield (less than two-methyl or ethyl substitutes) trends for high- $\mathrm{NO}_{x}$ conditions (Odum et al., 1997a, b) are not observed for low-NO $\mathrm{N}_{x}$ aromatic experiments in this study. Rather, high yield is observed only for benzene ( $\mathrm{Li}$ et al., 2016) while low yield is seen for substituted aromatic hydrocarbons. Similar SOA yield trends from different $\mathrm{C}_{8}$ and $\mathrm{C}_{9}$ aromatic isomers are further confirmed by comparing yields at similar radical conditions (Table S4, Fig. S3). It is also found that molecular structure exerts a greater impact on SOA yield than reaction kinetics (Supplement, Table S5). A two-product model described by Odum et al. (1996) is used to fit SOA yield curves as a function of $M_{o}$. The 12 aromatics are categorized into five groups to demonstrate the alkyl-group number and position effect on SOA formation. The five groups include a one-substitute group, ortho-position two-alkyl group (ortho), meta-position two-alkyl group (meta), para-position two-alkyl group (para) and three-substitute group. Fitting parameters $\left(\alpha_{1}, K_{\mathrm{om}, 1}\right.$, $\alpha_{2}$ and $K_{\mathrm{om}, 2}$; Table 2) in the two-product model are determined by minimizing the sum of the squared residuals. The lower-volatility partitioning parameter $\left(K_{\mathrm{om}, 2}\right)$ is the same for all yield curve fits by assuming similar high-volatile compounds are formed during all aromatic hydrocarbon photooxidation experiments. The ortho group is associated with a much higher $K_{\mathrm{om}, 1}$ compared with other aromatic groups, indicating that aromatic hydrocarbon oxidation with an orthoposition substitute forms much lower-volatility products than other isomers. $K_{\mathrm{om}, 1}$ is also slightly higher in the meta and one-substitute groups than in the three-substitute and parasubstitute groups.

A slight SOA yield difference remains within each group (Fig. S2 and Table S3), indicating the influence of factors other than alkyl-group position. Generally, lower yields are found in aromatics with alkyl groups of higher carbon number substitute, such as when comparing propylbenzene ( $i$ - and $n$-) with ethylbenzene or toluene (Li et al., 2016), $m$-ethyltoluene with $m$-xylene and $p$-ethyltoluene with $p$ xylene, respectively. These differences are explained by the proposed alkyl-group dilution effect (Sect. 4). However, the differences between xylenes and their corresponding ethyltoluenes are not statistically significant.

\subsection{Chemical composition}

\subsection{1 $f_{44}$ vs. $f_{43+57+71}$}

The ratio of alkyl substitute carbon number $(\mathrm{H}: \mathrm{C}>1)$ to the aromatic ring carbon number impacts SOA composition since the $\mathrm{H}: \mathrm{C}$ ratio on the alkyl substitute is larger than 1 and the $\mathrm{H}: \mathrm{C}$ ratio on the aromatic ring itself is no more than $1 . m / z 43\left(\mathrm{C}_{2} \mathrm{H}_{3} \mathrm{O}^{+}\right.$and $\left.\mathrm{C}_{3} \mathrm{H}_{7}^{+}\right)$combined with $m / z 44\left(\mathrm{CO}_{2}^{+}\right)$is critical to characterize oxygenated compounds in organic aerosol ( $\mathrm{Ng}$ et al., 2010, 2011). $\mathrm{C}_{2} \mathrm{H}_{3} \mathrm{O}^{+}$ is the major contributor to $\mathrm{m} / \mathrm{z}, 43$ in SOA formed from aromatic hydrocarbons, having only methyl substitute ( $\mathrm{Li}$ et al., 2016), while $\mathrm{C}_{3} \mathrm{H}_{7}^{+}$fragments are observed in this work for SOA from propylbenzene and isopropylbenzene (Fig. S5, Table S6). The $\mathrm{C}_{n} \mathrm{H}_{2 n-1} \mathrm{O}^{+}(n=$ carbon number of the alkyl substitute) fragment in SOA corresponds to a $\mathrm{C}_{n} \mathrm{H}_{2 n+1^{-}}$alkyl substitute to the aromatic ring. $\mathrm{C}_{3} \mathrm{H}_{5} \mathrm{O}^{+}$ $\left(m / z\right.$ 57) and $\mathrm{C}_{4} \mathrm{H}_{7} \mathrm{O}^{+}(m / z$ 71) are important when investigating SOA from ethyl- or propyl-substitute aromatic precursors. While $m / z 57\left(\mathrm{C}_{4} \mathrm{H}_{9}^{+}\right)$and $m / z 71\left(\mathrm{C}_{5} \mathrm{H}_{11}^{+}\right)$are often considered as markers for hydrocarbon-like organic aerosol in ambient studies (Zhang et al., 2005; Ng et al., 2010), oxygenated organic aerosol $\mathrm{C}_{3} \mathrm{H}_{5} \mathrm{O}^{+}$and $\mathrm{C}_{4} \mathrm{H}_{7} \mathrm{O}^{+}$are the major fragments at $m / z 57$ and $m / z 71$, respectively (Fig. S5, Table S6) in current chamber SOA studies, especially during the photooxidation of ethyl- and propyl-substituted aromatics. Therefore, $m / z 57$ and $m / z 71$ are also considered beside $\mathrm{C}_{2} \mathrm{H}_{3} \mathrm{O}^{+}$at $m / z 43$ in SOA chamber studies as oxygenated organic aerosol to compare the oxidation of differ- 
Table 2. Two-product yield curve fitting parameters for one-, two- and three-alkyl substitutes (ortho, meta and para).

\begin{tabular}{lrrrrr}
\hline Yield curve & $\alpha_{1}$ & $K_{\mathrm{om}, 1}\left(\mathrm{~m}^{3} \mu \mathrm{g}^{-1}\right)$ & $\alpha_{2}$ & $K_{\mathrm{Om}, 2}\left(\mathrm{~m}^{3} \mu \mathrm{g}^{-1}\right)$ & MSRE $^{*}$ \\
\hline One substitutes & 0.144 & 0.039 & 0.137 & 0.005 & 5.38 \\
Two substitutes (ortho) & 0.158 & 0.249 & 0.024 & 0.005 & 2.03 \\
Two substitutes (meta) & 0.156 & 0.040 & 0.080 & 0.005 & 2.51 \\
Two substitutes (para) & 0.154 & 0.025 & 0.036 & 0.005 & 1.21 \\
Three substitutes & 0.180 & 0.025 & 0.052 & 0.005 & 0.84 \\
\hline
\end{tabular}

Note: ${ }^{*}$ mean squared error $(\mathrm{MSRE})=[(\text { fitted yield }- \text { measured yield }) / \text { measured yield }]^{2} /($ number of data points $)$

ent aromatic hydrocarbons. Fig. S5 lists all fragments found at $m / z 43,44,57$ and 71 and Fig. S6 shows the fraction of each $m / z$ in SOA formed from all aromatic hydrocarbons studied. $m / z 43+m / z 44+m / z 57+m / z 71$ accounts for $21.2-$ $29.5 \%$ of the total mass fragments from all $\mathrm{C}_{8}$ and $\mathrm{C}_{9}$ aromatics studied, suggesting similar oxidation pathways. Only a small fraction $(<\sim 0.7 \%)$ of $m / z 71\left(\mathrm{C}_{4} \mathrm{H}_{7} \mathrm{O}^{+}\right)$or $m / z 57$ $\left(\mathrm{C}_{3} \mathrm{H}_{5} \mathrm{O}^{+}\right)$was observed in ethyltoluenes and trimethylbenzenes, respectively.

This work extends the traditional $f_{44}$ vs. $f_{43}\left(\mathrm{C}_{2} \mathrm{H}_{3} \mathrm{O}^{+}\right)$ chemical composition analysis by including oxidized fragments $\left(\mathrm{C}_{3} \mathrm{H}_{5} \mathrm{O}^{+} m / z 57\right.$ and $\mathrm{C}_{4} \mathrm{H}_{7} \mathrm{O}^{+} m / z$ 71) of the longer (non-methyl) alkyl substitutes. Therefore, $f_{44}$ vs. $f_{43}+f_{57}+$ $f_{71}$ is plotted instead of $f_{44}$ vs. $f_{43}$. Figure $\mathrm{S} 4$ shows the evolution of $f_{44}$ and $f_{43+57+71}$ in SOA formed from the photooxidation of different aromatic hydrocarbons at low- $\mathrm{NO}_{x}$ conditions. $f_{44}$ and $f_{43+57+71}$ ranges are comparable to previous chamber studies ( $\mathrm{Ng}$ et al., 2010; Chhabra et al., 2011; Loza et al., 2012; Sato et al., 2012). Only slight $f_{44}$ and $f_{43+57+71}$ evolution during chamber photooxidation is observed for the $\mathrm{C}_{8}$ and $\mathrm{C}_{9}$ isomers; hence only the average $f_{44}$ and $f_{43+57+71}$ will be analyzed in this work .

A modification is applied to the mass-based $\mathrm{m} / \mathrm{z}$ fraction in order to compare the mole relationship between $m / z 44$ and $m / z 43+m / z 57+m / z 71$ (Eq. 1).

$f^{\prime}{ }_{43+57+71}=\frac{44}{43} f_{43}+\frac{44}{57} f_{57}+\frac{44}{71} f_{71}$

The average $f_{44}$ vs. $f_{43+57+71}^{\prime}$ for all $\mathrm{C}_{8}$ and $\mathrm{C}_{9}$ isomers (Fig. 2) are located around the trend line for methyl-groupsubstituted aromatic hydrocarbons ( $\mathrm{Li}$ et al., 2016), implying a similarity in the SOA components formed from alkyl-substituted aromatic hydrocarbons. A decreasing trend in oxidation from upper left to lower right is included in Fig. 2, similar to what $\mathrm{Ng}$ et al. (2011) found in the $f_{44}$ vs. $f_{43}$ graph, especially while comparing similar structure compounds. The methyl-group location on the aromatic ring impacts $f_{44}: f_{43+57+71}^{\prime}$. Decreasing $f_{44}$ and increasing $f_{43+57+71}^{\prime}$ trends are observed from $p$-xylene to $o$-xylene to $m$-xylene and from 1,2,4-trimethylbenzene to 1,2,3trimethylbenzene to 1,3,5-trimethylbenzene. $f_{43+57+71}^{\prime}$ may partially depend on the relative position between the alkyl substitute and the peroxide oxygen of the bicyclic peroxide.

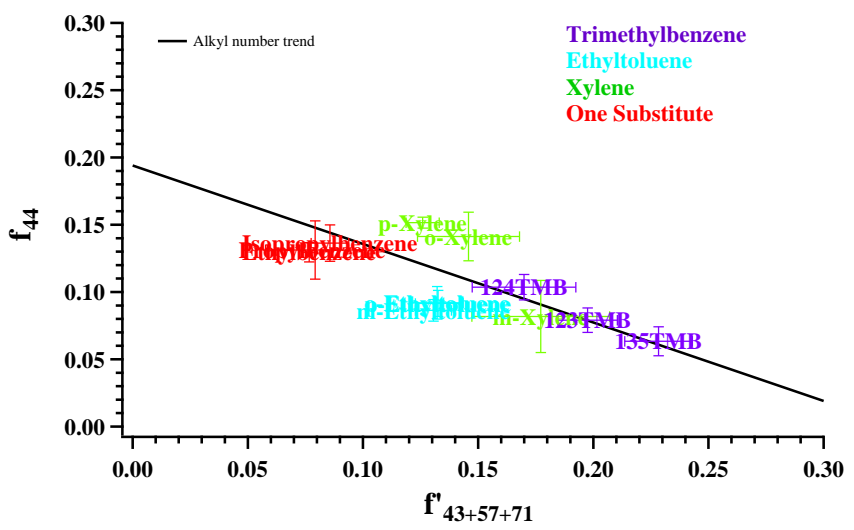

Figure 2. $f_{44+}$ vs. $f_{43+57+71}^{\prime}$ in SOA formed from different aromatic hydrocarbon photooxidation under low- $\mathrm{NO}_{x}$ colored by aromatic isomer type and marked with individual aromatic hydrocarbon species: ethylbenzene 2084A; propylbenzene $1245 \mathrm{~A}$; isopropylbenzene $1247 \mathrm{~A} ; m$-xylene 1191A; $m$-ethyltoluene 1199A; $o$-xylene 1320A; $o$-ethyltoluene 1179A; $p$-xylene 1308A; p-ethyltoluene 1194A; 1,2,3-trimethylbenzene (123TMB) 1162A; 1,2,4-trimethylbenzene (124TMB) 1119A; 1,3,5-trimethylbenzene (135TMB) 1156A. Alkyl number trend is the linear fitting in ( $\mathrm{Li}$ et al., 2015). * Error bar stands for $f_{44+}$ and $f_{43+57+71}^{\prime}$ standard deviation when significant particles are formed $\left(>5 \mu \mathrm{g} \mathrm{m}^{-3}\right)$.

For instance, allylically stabilized five-membered bicyclic radicals are the most stable bicyclic radical formed from aromatic hydrocarbon photooxidation (Andino et al., 1996). Two meta-position substitutes connected to the aromatic ring carbon with -C-O- yield higher fractions of $\mathrm{C}_{n} \mathrm{H}_{2 n-1} \mathrm{O}^{+}$ fragments than the para and ortho position, which have at most one substitute connected with -C-O- (Fig. S7). $\mathrm{CO}_{2}^{+}$ is generally formed during MS electrical ionization from carbonates, cyclic anhydrides and lactones (McLafferty and Turecek, 1993), indicating that the $\mathrm{CO}_{2}^{+}$is associated with -O-C-O- structure. Within the AMS, the $\mathrm{CO}_{2}^{+}$is also associated with decarboxylation of organic acids during heating followed by electrical ionization of the $\mathrm{CO}_{2}$. We hypothesize that $\mathrm{CO}_{2}^{+}$formation from bicyclic peroxides is insignificant since $\mathrm{CO}_{2}$ loss is not expected come from -C-O-O- structure during thermal decomposition. Therefore, it is the reaction products of bicyclic peroxides that lead to the formation of 
$\mathrm{CO}_{2}^{+}$and the difference in $f_{44}$. This indicates that the alkyl groups are more likely to contribute to SOA formation at the meta position than the ortho and para positions. Bicyclic peroxides formed from the $\mathrm{OH}$-addition reaction pathway and their dissociation reaction products are both used to explain the substitute location impact on the $f_{44}$ and $f_{43+57+71}^{\prime}$ relationship. However, the existence of longer alkyl substitutes diminishes the alkyl substitute location impact. SOA $f_{44}$ and $f_{43+57+71}^{\prime}$ in ethyltoluenes are all analogous to $m$-xylene. One-substitute $\mathrm{C}_{8}$ and $\mathrm{C}_{9}$ aromatic hydrocarbons have similar $f_{44}$ and $f_{43+57+71}^{\prime}$ with slightly lower $f_{44}$ and $f_{43+57+71}^{\prime}$ compared to toluene (Li et al., 2016). Longer alkyl substitutes may not lower the average oxidation per mass as further oxidation of the longer-chain alkyls may render other oxidized components not included in Fig. 2. Their lower total $f_{44}+f_{43+57+71}^{\prime}$ (Fig. S6) further supports the possibility of oxidation of the longer alkyl substitutes. It is also possible that oligomerization from highly oxidized carbonyls contributes more to the SOA formation from aromatics with long-chain alkyl substitute. Elemental ratio (Sect. 3.2.2) and oxidation state (Sect. 3.2.3) are further used to evaluate the impact of increasing alkyl-group size on SOA formation.

\subsubsection{H / C vs. O / C}

Elemental analysis (Aiken et al., 2007, 2008) serves as a valuable tool to elucidate SOA chemical composition and SOA formation mechanisms (Heald et al., 2010; Chhabra et al., 2011). Figure S8 shows $\mathrm{H} / \mathrm{C}$ and $\mathrm{O} / \mathrm{C}$ evolution in SOA formed from the photooxidation of different aromatic hydrocarbons under low $\mathrm{NO}_{x}$ (marked and colored similarly to Fig. S4). $\mathrm{H} / \mathrm{C}$ and $\mathrm{O} / \mathrm{C}$ ranges are comparable to previous chamber studies (Chhabra et al., 2011, $m$-xylene and toluene; Loza et al., 2012, $m$-xylene; Sato et al., 2012, benzene and 1,3,5-trimethylbenzene). The SOA elemental ratio for $\mathrm{C}_{8}$ and $\mathrm{C}_{9}$ aromatic isomers are located near the alkyl number trend line found by Li et al. (2016) for methyl substituents, indicating a similarity between SOA from various alkyl-substituted hydrocarbons. SOA formed is among the low-volatility oxygenated organic aerosol (LV-OOA) and semi-volatile oxygenated organic aerosol (SV-OOA) regions ( $\mathrm{Ng}$ et al., 2011). The evolution trend agrees with Fig. S4 (Sect. 3.2.1), which means no significant $\mathrm{H} / \mathrm{C}$ and $\mathrm{O} / \mathrm{C}$ evolution is observed in the current study. Therefore, average $\mathrm{H} / \mathrm{C}$ and $\mathrm{O} / \mathrm{C}$ with standard deviation provided is used to explore the impact of molecular structure on SOA chemical composition. The current study concentrates on experimentally averaged $\mathrm{H}$ / C and $\mathrm{O} / \mathrm{C}$ to explore the impact of molecular structure on SOA chemical composition.

Average $\mathrm{H} / \mathrm{C}$ and $\mathrm{O} / \mathrm{C}$ locations are marked with aromatic compound names in Fig. 3. All $\mathrm{H} / \mathrm{C}$ and $\mathrm{O} / \mathrm{C}$ are located around the predicted values for $\mathrm{C}_{8}$ and $\mathrm{C}_{9} \mathrm{SOA}$ (dark solid circle) based on the elemental ratio of benzene SOA (Li et al., 2016). This confirms the presence of a carbon dilution effect in all isomers. Ortho-position

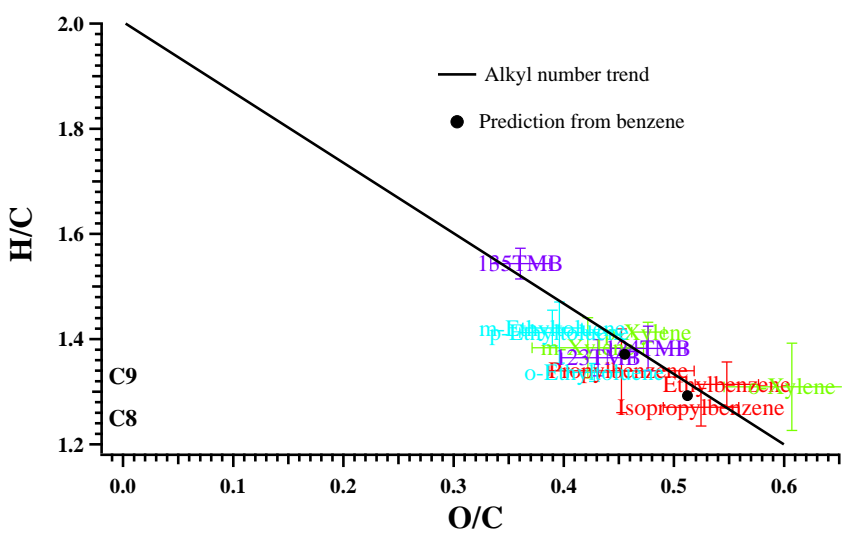

Figure 3. H / C vs. O / C in SOA formed from different aromatic hydrocarbon photooxidation under low $\mathrm{NO}_{x}$, colored by aromatic isomer type and marked with individual aromatic hydrocarbon species (C8 and C9 on the lower left indicate the location of initial aromatic hydrocarbon precursor): ethylbenzene 2084A; propylbenzene 1245A; isopropylbenzene 1247A; $m$-xylene 1191A; $m$-ethyltoluene 1199A; o-xylene 1320A; o-ethyltoluene 1179A; p-xylene 1308A; $p$-ethyltoluene 1194A; 1,2,3-trimethylbenzene (123TMB) 1162A; 1,2,4-trimethylbenzene(124TMB) 1119A; 1,3,5-trimethylbenzene(135TMB) 1156A. Alkyl number trend is the linear fitting in Li et al. (2015a). Solid black circles are SOA elemental ratios from $\mathrm{C}_{8}$ and $\mathrm{C}_{9}$ aromatic hydrocarbon predicted by SOA elemental ratio formed from benzene. ${ }^{*}$ Error bar stands for $\mathrm{H} / \mathrm{C}$ and $\mathrm{O} / \mathrm{C}$ standard deviation when significant particles are formed $\left(>5 \mu \mathrm{g} \mathrm{m}^{-3}\right)$.

aromatic hydrocarbons (o-xylene or $o$-ethyltoluene) lead to a more oxidized SOA (higher $\mathrm{O} / \mathrm{C}$ and lower $\mathrm{H} / \mathrm{C}$ ) than that of meta ( $m$-xylene or $m$-ethyltoluene) and para ( $p$-xylene or $p$-ethyltoluene) aromatics. SOA formed from 1,2,4-trimethylbenzene and 1,2,3-trimethylbenzene is more oxidized than that from 1,3,5-trimethylbenzene. It is noticed that 1,2,4-trimethylbenzene and 1,2,3-trimethylbenzene both contain an ortho-position moiety on the aromatic ring. This indicates that the ortho-position aromatic hydrocarbon is readily oxidized and this ortho-position impact on oxidation extends to triple-substituted aromatic hydrocarbons. Substitute length also plays an important role in aromatic hydrocarbon oxidation. Overall, SOA from a one-substitute aromatic with more carbon in the substitute is located at a more oxidized area of the $\mathrm{O} / \mathrm{C}$ vs. $\mathrm{H} / \mathrm{C}$ chart (lower right in Fig. 3) than those multiple-substitute aromatic isomers with the same total number of carbon as the single-substituted aromatic. SOA from isopropylbenzene is located in a lower position of the chart and to the right of propylbenzene, indicating that branch carbon structure on the alkyl substitute of aromatic hydrocarbons leads to a more oxidized SOA. Lines in Fig. S8 connect the $\mathrm{O} / \mathrm{C}$ and $\mathrm{H} / \mathrm{C}$ of resulting SOA to that of the aromatic precursor. Most SOA components show a slight $\mathrm{H} / \mathrm{C}$ increase and a dramatic $\mathrm{O} / \mathrm{C}$ increase from the precursor, which is consistent with results observed 
for methyl-substituted aromatics ( $\mathrm{Li}$ et al., 2016). However, $\mathrm{H} / \mathrm{C}$ barely increases (1.33 to 1.34 ) from the propylbenzene precursor to its resulting SOA and there is even a decreasing trend from isopropylbenzene to its SOA. This indicates that a high $\mathrm{H} / \mathrm{C}$ component loss reaction such as alkyl-part dissociation during photooxidation is an important reaction to SOA formation from aromatic hydrocarbons containing longer carbon chains. The carbon chain length of propylbenzene increases the possibility of alkyl fragmentation. The branching structure of isopropylbenzene facilitates fragmentation through the stability of tertiary alkyl radicals. Elemental ratio differences between xylenes and ethyltoluenes can be attributed to the alkyl dilution effect, similar to the methyl dilution theory by Li et al. (2016). Prediction of elemental ratios from toluene and xylenes is discussed later (Sect. 4) to further quantify the carbon length and branching effect on SOA formation from aromatic hydrocarbons.

\subsection{3 $\mathrm{OS}_{\mathrm{c}}$}

Oxidation state $\left(\mathrm{OS}_{\mathrm{c}} \approx 2 \mathrm{O} / \mathrm{C}-\mathrm{H} / \mathrm{C}\right)$ was introduced into aerosol-phase component analysis by Kroll et al. (2011). It is considered to be a more accurate metric for describing oxidation in atmospheric organic aerosol than $\mathrm{H} / \mathrm{C}$ and $\mathrm{O} / \mathrm{C}(\mathrm{Ng}$ et al., 2011; Canagaratna et al., 2015; Lambe et al., 2015) and therefore well correlated with gas-particle partitioning (Aumont et al., 2012;). Average $\mathrm{OS}_{\mathrm{c}}$ of SOA formed from $\mathrm{C}_{8}$ and $\mathrm{C}_{9}$ aromatic isomers ranges from -0.54 to -0.17 and -0.82 to -0.22 , respectively (Fig. 4), implying that the precursor molecular structure impacts the $\mathrm{OS}_{\mathrm{c}}$ of the resulting SOA. An $\mathrm{OS}_{\mathrm{c}}$ decrease with alkyl substitute length is observed in one-substitute aromatic hydrocarbons from toluene (toluene $\mathrm{OS}_{\mathrm{c}}=-0.049$; $\mathrm{Li}$ et al. 2016) to propylbenzene. However, $\mathrm{OS}_{\mathrm{c}}$ provides the average oxidation value per carbon without considering whether these carbons start from an aromatic ring carbon or an alkyl carbon. Alkyl carbons are associated with more hydrogen than aromatic ring carbons, thus leading to a lower precursor $\mathrm{OS}_{\mathrm{c}}$ and therefore lower SOA OS $\mathrm{c}$. Dilution conjecture in Sect. 4 will be used to further explore the carbon chain length effect on aromatic hydrocarbon oxidation by considering the precursor $\mathrm{H}$ : C ratio. Single-substitute aromatic hydrocarbons generally show higher $\mathrm{OS}_{\mathrm{c}}$ than multiple-substitute ones, consistent with the yield trend of Odum et al. (1997b). However, it is also found that ortho-position moiety containing twoor three-substitute aromatic hydrocarbons have analogous or even higher $\mathrm{OS}_{\mathrm{c}}$ to single-substitute aromatic hydrocarbons (o-xylene $-0.03 \pm 0.098$ to ethylbenzene $-0.173 \pm 0.033$; 1,2,4-trimethylbenzene $-0.425 \pm 0.072$ and $o$-ethyltoluene $-0.481 \pm 0.030$ to propylbenzene $-0.421 \pm 0.111$ ). This suggests that both substitute number and position are critical to aromatic hydrocarbon oxidation and therefore SOA formation. $\mathrm{OS}_{\mathrm{c}}$ trends also support that the meta position suppresses oxidation while the ortho position promotes oxidation when the $\mathrm{OS}_{\mathrm{c}}$ of xylenes $(o$-xylene $>p$-xylene

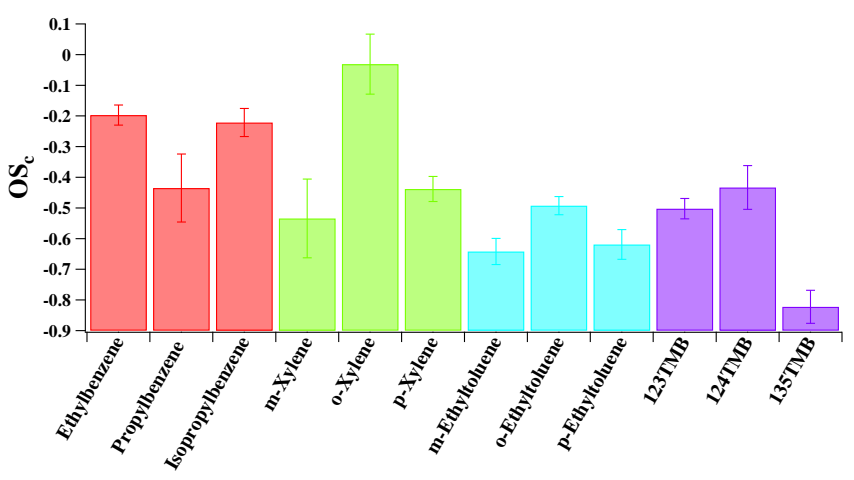

Figure 4. Oxidation state $\left(\mathrm{OS}_{\mathrm{c}}\right)$ of $\mathrm{SOA}$ formed from different aromatic hydrocarbon photooxidation under low $\mathrm{NO}_{x}$ : ethylbenzene 2084A; propylbenzene 1245A; isopropylbenzene 1247A; $m$-xylene 1191A; $m$-ethyltoluene 1199A; $o$ xylene 1320A; $o$-ethyltoluene 1179A; $p$-xylene 1308A; p-ethyltoluene 1194A; 1,2,3-trimethylbenzene (123TMB) 1162A; 1,2,4-trimethylbenzene(124TMB) 1119A; 1,3,5trimethylbenzene(135TMB) 1156A.

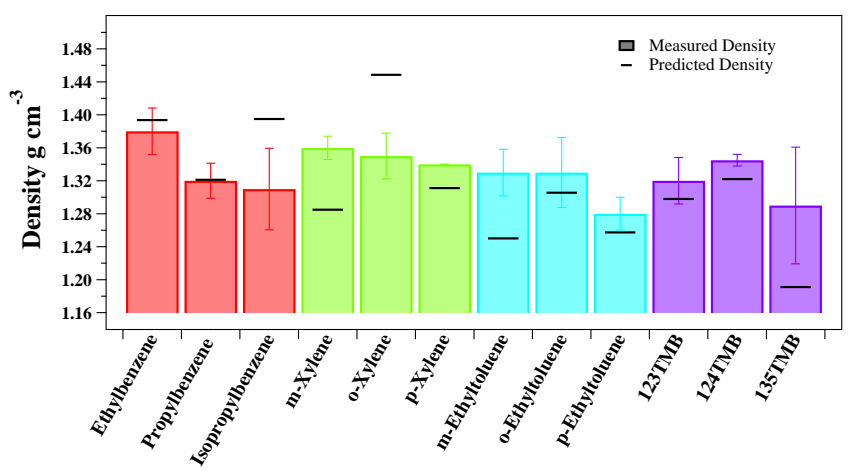

Figure 5. Measured and predicted SOA density from different aromatic hydrocarbon photooxidation under low $\mathrm{NO}_{x}$ (colored with substitute number and length: one substitute is red, xylenes are green, ethyltoluenes are blue and trimethylbenzene is purple; black line is predicted density according to Kuwata et al., 2011); 123TMB is 1,2,3-Trimethylbenzene; $135 \mathrm{TMB}$ is $1,3,5$-Trimethylbenzene; 124TMB is 1,2,4-Trimethylbenzene.

$>$ (insignificant) $m$-xylene), ethyltoluenes (o-ethyltoluene $>p$-ethyltoluene $>$ (insignificant) $m$-ethyltoluene) and especially trimethylbenzenes (1,2,4-trimethylbenzene (ortho moiety containing) $>$ (insignificant) 1,2,3-trimethylbenzene (ortho moiety containing) > 1,3,5-trimethylbenzene (meta moiety containing)) are compared separately. Further, SOA formed from isopropylbenzene shows the highest $\mathrm{OS}_{\mathrm{c}}$ among all $\mathrm{C}_{9}$ isomers, nearly equivalent to that of ethylbenzene. This demonstrates that the branching structure of the alkyl substitute can enhance further oxidation of aromatic hydrocarbons. 
Table 3. Correlation among SOA density, volatility (VFR) and SOA chemical composition.

\begin{tabular}{lrrrrrrr}
\hline & $f_{44}$ & $f_{57}$ & $f_{71}$ & $\mathrm{O} / \mathrm{C}$ & $\mathrm{H} / \mathrm{C}$ & $\mathrm{OS}_{\mathrm{c}}$ & $k_{\mathrm{OH}}$ \\
\hline Density $^{\mathrm{b}}$ & 0.324 & -0.056 & -0.38 & 0.551 & -0.301 & 0.540 & -0.249 \\
$p$ value $^{\mathrm{b}}$ & 0.304 & 0.862 & 0.223 & 0.063 & 0.341 & 0.070 & 0.435 \\
\hline VFR $_{\text {end }}^{\mathrm{a}}$ & 0.537 & 0.56 & 0.399 & 0.471 & -0.586 & 0.593 & -0.937 \\
$p$ value $^{\mathrm{b}}$ & 0.089 & 0.073 & 0.224 & 0.144 & 0.058 & 0.055 & 0.000 \\
\hline
\end{tabular}

Note: ${ }^{\mathrm{a}} \mathrm{VFR}_{\text {end }}$ is the volume fraction remaining at the end of photooxidation. ${ }^{\mathrm{b}} p$ values range from 0 to 1: 0 indicates rejection of the null hypothesis and 1 is acceptance of the null hypothesis. Alpha $(\alpha)$ level used is 0.05 . If the $p$ value of a test statistic is less than $\alpha$, the null hypothesis is rejected.

\subsection{Physical property}

\subsubsection{SOA density}

SOA density is a fundamental parameter in understanding aerosol morphology, dynamics, phase and oxidation (DeCarlo et al., 2004; Katrib et al., 2005; Dinar et al., 2006; Cross et al., 2007). SOA density ranges from 1.29 to $1.38 \mathrm{~g} \mathrm{~cm}^{-3}$ from aromatic photooxidation under low$\mathrm{NO}_{x}$ conditions in this study (Fig. 5). The range is comparable to previous studies under similar conditions (Borrás and Tortajada-Genaro, 2012; Ng et al., 2007; Sato et al., 2010). There is no significant difference in the density of SOA formed from $\mathrm{C}_{8}$ and $\mathrm{C}_{9}$ aromatic hydrocarbon isomers and molecular structure is not observed to be a critical parameter to determine SOA density. The standard deviation results from differences in initial conditions (e.g., initial HC / NO) that also determine the oxidation of aromatic hydrocarbons (Li et al., 2015) and thus further affect density. SOA density is correlated with the $\mathrm{O} / \mathrm{C}$ ratio and $\mathrm{OS}_{\mathrm{c}}(0.551$ and 0.540 , Table 3), consistent with the observation of Pang et al. (2006) that SOA density increases with increasing $\mathrm{O} / \mathrm{C}$ ratio. The density prediction method developed by Kuwata et al. (2011) based on $\mathrm{O} / \mathrm{C}$ and $\mathrm{H} / \mathrm{C}$ is evaluated as

$\rho=\frac{12+\mathrm{H} / \mathrm{C}+16 \times \mathrm{O} / \mathrm{C}}{7+5 \times \mathrm{H} / \mathrm{C}+4.15 \times \mathrm{O} / \mathrm{C}}$.

The black lines (Fig. 5) are predicted (Eq. 2) densities and show a good agreement between predicted and measured SOA densities (difference between prediction and measurement is $-6.01-7.62 \%$ ). A comparatively large negative error is found in meta-containing aromatic hydrocarbons, including $m$-xylene, $m$-ethyltoluene and 1,3,5-trimethylbenzene. It is noted that there should be more alkyl substitutes in SOA formed from meta-position aromatics than other aromatics since meta-position alkyl substitutes are more likely to participate into SOA products than other aromatics (Sect. 3.2.1 and 3.2.2). Previous work suggests that the increase of methyl groups could lead to a change in several key organic fragments (e.g., $\mathrm{CO}^{+}, \mathrm{CO}_{2}^{+}$and $\mathrm{H}_{2} \mathrm{O}^{+}$), thereby altering the default fragment table for elemental ratio analysis. This agrees with the density underestimation in SOA formed from meta-position aromatics and supports the preference of meta-position alkyl substitute to SOA products.

\subsubsection{SOA volatility}

SOA volatility is associated with reactions such as oxidation, fragmentation, oligomerization and mass loading (Kalberer et al., 2004; Salo et al., 2011; Tritscher et al., 2011; Yu et al., 2014). SOA volatility in this study is measured as VFR. Initial $(<30 \mathrm{~min}$ after new particle formation) SOA VFRs are around 0.2 for all the aromatic precursors studied and increase up to 0.58 during photooxidation. This suggests that aromatic hydrocarbon oxidation undergoes an evolution from volatile compounds to semivolatile compounds. The VFR trends and ranges are comparable to previous studies (Kalberer et al., 2004; Qi et al., 2010a, b; Nakao et al., 2012). Figure 6 shows the VFR at the end of aromatic hydrocarbon photooxidation $\left(\mathrm{VFR}_{\text {end }}\right)$. A decreasing $\mathrm{VFR}_{\text {end }}$ trend is found as the number of substitutes increase and for meta-position (e.g., $m$-xylene) or meta-position-containing (e.g., 1,3,5-trimethylbenzene) aromatic precursors. Correlations among $\mathrm{VFR}_{\mathrm{end}}$ and chemical composition are observed in the aromatic hydrocarbons studied here (Table 3). This is consistent with recent findings that $\mathrm{O}: \mathrm{C}$ ratio is correlated to aerosol volatility (Sect. 3.3.2) (Cappa and Wilson, 2012; Yu et al., 2014), thereby affecting the gas-particle partitioning, which in turn relates to SOA yield. It is also observed that $\mathrm{VFR}_{\text {end }}$ is strongly correlated $(-0.937)$ with reaction rate constant $\left(k_{\mathrm{OH}}\right)$. Higher $k_{\mathrm{OH}}$ is associated with faster reaction rates of initial aromatic precursors and is therefore expected to lead to further oxidation for a given reaction time. However, the inverse correlation between $k_{\mathrm{OH}}$ and $\mathrm{VFR}_{\text {end }}$ indicates that $k_{\mathrm{OH}}$ value represents more than just the kinetic aspects. $k_{\mathrm{OH}}$ increases with increasing number of substitutes on the aromatic ring. Additionally, aromatic hydrocarbons with meta-position substitutes have higher $k_{\mathrm{OH}}$ than those with para- and ortho-position (Table S1) substitutes. This suggests that the precursor molecular structures for aromatics associated with $k_{\mathrm{OH}}$ values determine the extent of oxidation of the hydrocarbons and therefore impact SOA volatility more than simply the precursor oxidation rate. 


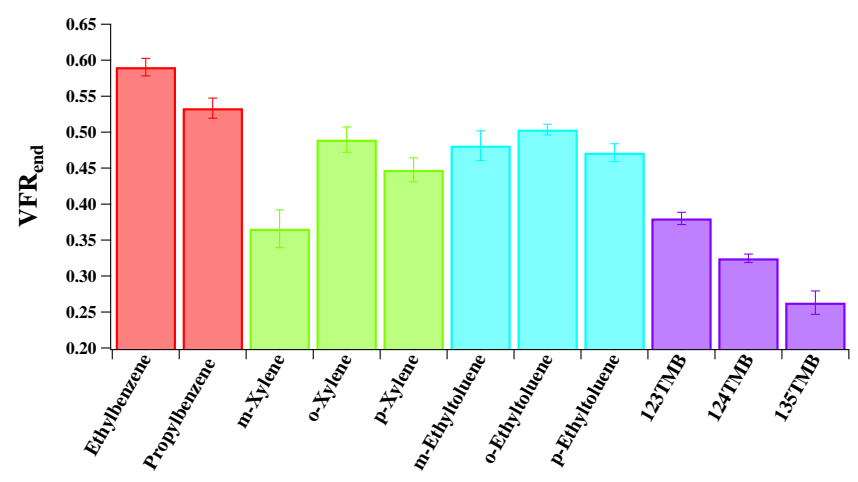

Figure 6. SOA volume fraction remaining $\left(\mathrm{VFR}_{\mathrm{end}}\right)$ at the end of aromatic hydrocarbon photooxidation under low $\mathrm{NO}_{x}$ (colored with substitute number and length: one substitute is red, xylenes are green, ethyltoluenes are blue and trimethylbenzene is purple); $123 \mathrm{TMB}$ is $1,2,3$-Trimethylbenzene; $135 \mathrm{TMB}$ is $1,3,5$ Trimethylbenzene; $124 \mathrm{TMB}$ is 1,2,4-Trimethylbenzene.

\section{Alkyl dilution conjecture on SOA formation from aromatic hydrocarbons}

The dependence of SOA formation on molecular structure can be partially represented by the alkyl carbon number. Carbon dilution theory proposed by Li et al. (2016) successfully explains that methyl-group impacts remain similar in SOA elemental ratios as in the aromatic precursor. The chemical composition of SOA formation from alkylsubstituted aromatics is predicted by simply adding the alkyl substitute into the chemical composition of SOA formed from pure aromatic ring precursor (benzene). Methyl dilution theory ( $\mathrm{Li}$ et al. 2016) is extended to alkyl substitute dilution conjecture in order to investigate the influence of longer alkyl substitutes compared with methyl-group substitutes. A robust prediction of SOA $\mathrm{H} / \mathrm{C}$ and $\mathrm{O} / \mathrm{C}$ trends for longer $(\mathrm{C} 2+)$ alkyl-substituted aromatics based on the methyl-substituted aromatics will suggest a similarity in the role of methyl and longer alkyl to SOA formation; an underestimation or overestimation will indicate different oxidation pathways for aromatics with differing alkyl substitute length. Figure $7 \mathrm{a}$ and $\mathrm{b}$ shows the predicted elemental ratio and $\mathrm{OS}_{\mathrm{c}}$ for SOA formed from longer alkyl substitutes $\left(-\mathrm{C}_{n} \mathrm{H}_{2 n+1}\right.$, $n>1$ ) based on methyl-only substitute. The elemental ratio of SOA formed from single-substitute aromatic hydrocarbons including ethylbenzene, propylbenzene and isopropylbenzene is predicted by toluene and those of ethyltoluenes are predicted by corresponding xylenes with similar alkyl substitute location. $\mathrm{H} / \mathrm{C}$ and $\mathrm{O} / \mathrm{C}$ are generally well predicted by alkyl dilution effect, except for $o$-ethyltoluene and iso-propylbenzene. O / C (15\%), $\mathrm{H} / \mathrm{C}(1 \%)$ and $\mathrm{OS}_{\mathrm{c}}(13 \%)$ of $o$-ethyltoluene are slightly overestimated by alkyl dilution effect. This indicates that $o$-ethyltoluene is less oxidized than $o$-xylene possibly due to the hindrance effect of the longer alkyl substitute.
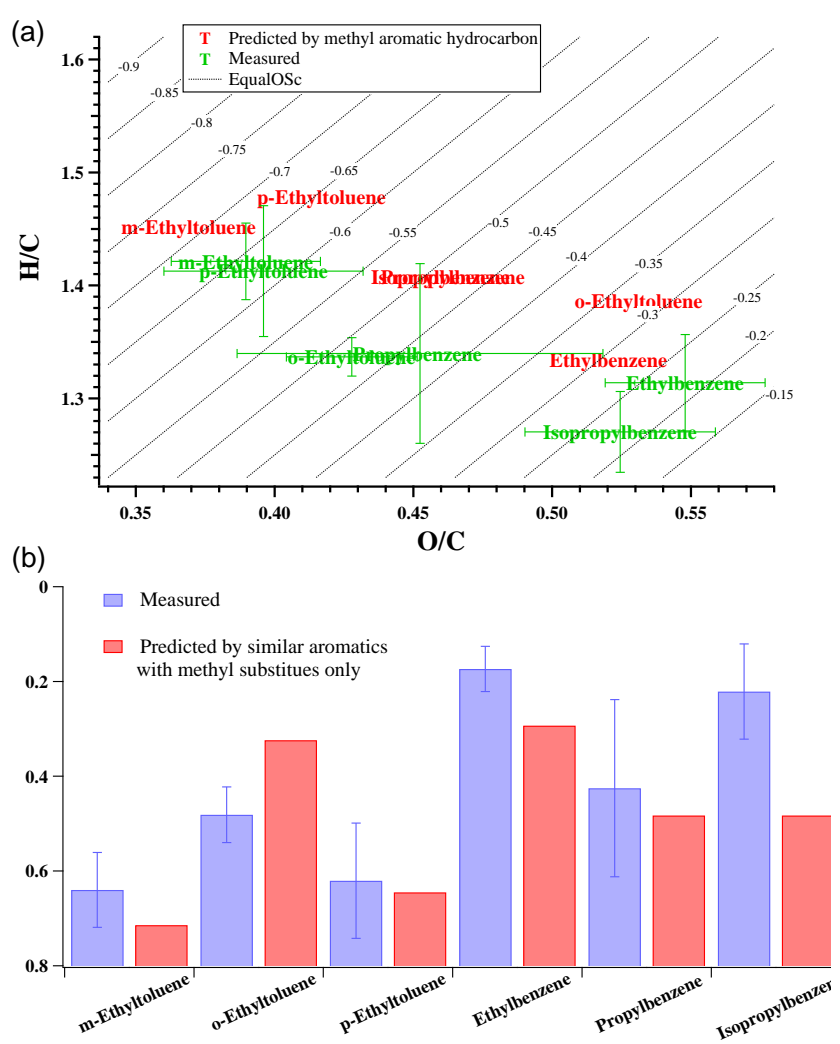

Figure 7. Comparison of measured and predicted elemental ratio (a) and oxidation state (b) of SOA formed from longer alkyl substitute $\left(-\mathrm{C}_{2} \mathrm{H}_{2 n+1}, n>1\right)$. Ethyltoluenes are predicted by corresponding xylenes and one-substitute aromatic hydrocarbons are predicted by toluene. ${ }^{*}$ Predicted elemental ratio of isopropylbenzene is same as propylbenzene (not shown in Fig. 7a).

$\mathrm{OS}_{\mathrm{c}}$ is underestimated in SOA formed from singlesubstitute aromatic hydrocarbons, especially for isopropylbenzene $(-49 \%)$ and ethylbenzene $(-25 \%)$. This implies that longer alkyl substitutes are more oxidized than the methyl group on toluene. A direct $\cdot \mathrm{OH}$ reaction with the alkyl part of the aromatic is more favored on longer alkyl chains since tertiary and secondary alkyl radicals are more stable than primary alkyl radicals (Forstner et al., 1997). It is also possible that oligomerization from highly oxidized carbonyl component might be more favored for long-chain singlealkyl-substituted aromatics. The less significant $\mathrm{OS}_{\mathrm{c}}$ underestimation from xylenes to ethyltoluenes (meta and para) is due to the presence of an "inert" methyl group which lowers the average $\mathrm{OS}_{\mathrm{c}}$. Fragmentation on alkyl substitute of isopropylbenzene can lead to a higher $\mathrm{OS}_{\mathrm{c}}(-0.22 \pm 0.04)$ than propylbenzene $(-0.42 \pm 0.11)$, which possibly occurs while forming 2,5-furandione or 3- $H$-furan-2-one due to the increased stability of the isopropyl radical compared to the n-propyl radical. It is also possible that longer carbon chain substitutes might have higher probability to form other cyclic or low-vapor pressure products by additional reaction due to 
their increased length. The similarity in $f_{44}$ and $f_{43+57+71}^{\prime}$ but discrepancy (insignificant) in elemental ratio among all single-substitute $\mathrm{C}_{8}$ and $\mathrm{C}_{9}$ aromatics support that additional reactions leading to further oxidization of alkyl substitutes can occur.

\section{Atmospheric implication}

This study elucidates molecular structure impact on a major anthropogenic SOA source, photooxidation of aromatic hydrocarbons, under atmospherically relevant $\mathrm{NO}_{x}$ conditions by analyzing SOA yield, chemical composition and physical properties. These observations, when taken together, indicate the roles of alkyl substitute number, location, carbon chain length and branching structure in aromatic hydrocarbon photooxidation. SOA yield of all $\mathrm{C}_{8}$ and $\mathrm{C}_{9}$ aromatic hydrocarbon isomers is comprehensively provided in this study with a focus on the impact of molecular structure. It is demonstrated that aromatic hydrocarbon oxidation and SOA formation should not be simply explained by substitute number. The promoting of SOA formation by the ortho position is found along with confirmation of the suppression effect by the para position during oxidation of aromatic hydrocarbons. It is possibly due to the alkyl substitute location impact on the further oxidation of five-membered bicyclic radicals. Different carbonyl compounds can form as the ring opening products from the dissociation of five-membered bicyclic radical. It is assumed that oligomerization of these carbonyl compounds can contribute to SOA (Li et al., 2016). Aromatic hydrocarbons with para-position alkyl substitute tend to form more ketone-like dicarbonyl compounds than other aromatics. Ketone might contribute less to oligomerization formation compared with aldehyde as suggested in Li et al. (2016). Meta-position alkyl substitutes on aromatic ring lead to a lower extent of aromatic hydrocarbon oxidation. This might be due to a higher percentage of carbonyl with alkyl substitute formed during the oxidation of meta-containing aromatics (e.g., methylglyoxal, 2-methyl-4-oxopent-2-enal), which contributes to oligomerization and thereby SOA formation. Evidence is provided to demonstrate aromatic oxidation increase with alkyl substitute chain length and branching structure. Further, the carbon dilution theory developed by Li. et al. (2016) is extended to this study. Carbon dilution theory not only serves as a tool to explain the difference in SOA components due to the difference in substitute alkyl carbon number but also acts as a standard to determine the oxidation mechanism based on alkyl substitute structure. Moreover, the five subcategories of aromatics and their two-product modeling curve fitting parameters in this work at more realistic $\mathrm{NO}_{x}$ loadings provide a more precise prediction of SOA formation form aromatic hydrocarbons under atmospheric conditions. Previous studies found that the humidity insignificantly impacts SOA yield from aromatic hydrocarbons (Cocker et al., 2001) or maintains the SOA yield re- lationship between isomers (Zhou et al., 2011). Therefore, it is predicted that the observation found under dry conditions in this study, especially the molecular structure impact on SOA formation from different aromatic isomers, could be extended to atmospherically relevant humidity conditions. However, recent studies observe that the hydration of carbonyls and epoxides could lead to further heterogeneous reaction and oligomerization (Jang et al., 2002; Liggio et al., 2005; Minerath and Elrod, 2009; Lal et al., 2012). It is possible that aerosol compositions and the hygroscopic properties could be altered after the heterogeneous reactions, especially under humid conditions. The impact of molecular structure impact on SOA formation under humidity condition needs to be further studied to extend the findings in current the work. This study improves the understanding of SOA formation from aromatic hydrocarbons and contributes to more accurate SOA prediction from aromatic precursors. Further study is warranted to reveal the detailed oxidation pathway of aromatic hydrocarbons with longer (carbon number $>1$ ) alkyl substitutes.

\section{Data availability}

The underlying data are not publically accessible at this time due to size constraints and lack of common public data repository format for the data sets obtained within this work. All data are available upon request.

\section{The Supplement related to this article is available online at doi:10.5194/acp-16-10793-2016-supplement.}

Acknowledgements. We acknowledge funding support from National Science Foundation (ATM 0901282) and W. M. Keck Foundation.

Disclaimer. Any opinions, findings and conclusions expressed in this material are those of the author(s) and do not necessarily reflect the views of the NSF.

Edited by: F. Keutsch

Reviewed by: four anonymous referees

\section{References}

Aiken, A. C., DeCarlo, P. F., and Jimenez, J. L.: Elemental analysis of organic species with electron ionization highresolution mass spectrometry, Anal. Chem., 79, 8350-8358, doi:10.1021/ac071150w, 2007.

Aiken, A. C., DeCarlo, P. F., Kroll, J. H., Worsnop, D. R., Huffman, J. A., Docherty, K. S., Ulbrich, I. M., Mohr, C., Kimmel, J. R., Sueper, D., Sun, Y., Zhang, Q., Trimborn, A., Northway, 
M., Ziemann, P. J., Canagaratna, M. R., Onasch, T. B., Alfarra, M. R., Prevot, A. S. H., Dommen, J., Duplissy, J., Metzger, A., Baltensperger, U., and Jimenez, J. H.: O / C and OM / OC ratios of primary, secondary, and ambient organic aerosols with highresolution time-of-flight aerosol mass spectrometry, Environ. Sci. Technol., 42, 4478-4485, doi:10.1021/es703009q, 2008.

Andino, J. M., Smith, J. N., Flagan, R. C., Goddard, W. A., and Seinfeld, J. H.: Mechanism of atmospheric photooxidation of aromatics: A theoretical study, J. Phys. Chem.-US, 100, 1096710980, doi:10.1021/jp9529351, 1996.

Atkinson, R.: A structure-activity relationship for the estimation of rate constants for the gas-phase reactions of $\mathrm{OH}$ radicals with organic compounds, Int. J. Chem. Kinet., 19, 799-828, doi:10.1002/kin.550190903, 1987.

Atkinson, R. and Arey, J.: Atmospheric degradation of volatile organic compounds, Chem. Rev., 103, 4605-4638, doi:10.1021/cr0206420, 2003.

Aumont, B., Valorso, R., Mouchel-Vallon, C., Camredon, M., LeeTaylor, J., and Madronich, S.: Modeling SOA formation from the oxidation of intermediate volatility $n$-alkanes, Atmos. Chem. Phys., 12, 7577-7589, doi:10.5194/acp-12-7577-2012, 2012.

Bahreini, R., Ervens, B., Middlebrook, A., Warneke, C., De Gouw, J., DeCarlo, P., Jimenez, J., Brock, C., Neuman, J., Ryerson, T., Stark, H., Atlas, E., Brioude, J., Fried, A., Holloway, J. S., Peischl, J., Richter, D., Walega, J., Weibring, P., Wollny, A. G., and Fehsenfeld, F. C.: Organic aerosol formation in urban and industrial plumes near Houston and Dallas, Texas, J. Geophys. Res.Atmos., 114, D00F16, doi:10.1029/2008JD011493, 2009.

Borrás, E. and Tortajada-Genaro, L. A.: Secondary organic aerosol formation from the photo-oxidation of benzene, Atmos. Environ., 47, 154-163, doi:10.1016/j.atmosenv.2011.11.020, 2012.

Calvert, J. G., Atkinson, R., Becker, K. H., Kamens, R. M., Seinfeld, J. H., Wallington, T. J., and Yarwood, G.: The mechanisms of atmospheric oxidation of aromatic hydrocarbons, Oxford University Press, New York, USA, 2002.

Canagaratna, M. R., Jayne, J. T., Jimenez, J. L., Allan, J. D., Alfarra, M. R., Zhang, Q., Onasch, T. B., Drewnick, F., Coe, H., Middlebrook, A., Delia, A., Williams, L. R., Trimborn, A. M., Northway, M. J., DeCarlo, P. F., Kolb, C. E., Davidovits, P., and Worsnop D. R.: Chemical and microphysical characterization of ambient aerosols with the aerodyne aerosol mass spectrometer, Mass. Spectrom. Rev., 26, 185-222, doi:10.1002/mas.20115, 2007.

Canagaratna, M. R., Jimenez, J. L., Kroll, J. H., Chen, Q., Kessler, S. H., Massoli, P., Hildebrandt Ruiz, L., Fortner, E., Williams, L. R., Wilson, K. R., Surratt, J. D., Donahue, N. M., Jayne, J. T., and Worsnop, D. R.: Elemental ratio measurements of organic compounds using aerosol mass spectrometry: characterization, improved calibration, and implications, Atmos. Chem. Phys., 15, 253-272, doi:10.5194/acp-15-253-2015, 2015.

Cappa, C. D. and Wilson, K. R.: Multi-generation gas-phase oxidation, equilibrium partitioning, and the formation and evolution of secondary organic aerosol, Atmos. Chem. Phys., 12, 9505-9528, doi:10.5194/acp-12-9505-2012, 2012.

Carter, W. P. L. and Heo, G.: Development of Revised SAPRC Aromatics Mechanisms, Atmos. Environ., 77, 404-414, doi:10.1016/j.atmosenv.2013.05.021, 2013.

Carter, W. P. L., Cocker III, D. R., Fitz, D. R., Malkina, I.L., Bumiller, K., Sauer, C.G., Pisano, J.T., Bufalino, C., and Song, C.:
A new environmental chamber for evaluation of gas-phase chemical mechanisms and secondary aerosol formation, Atmos. Environ., 39, 7768-7788, doi:10.1016/j.atmosenv.2005.08.040, 2005.

Chhabra, P. S., Ng, N. L., Canagaratna, M. R., Corrigan, A. L., Russell, L. M., Worsnop, D. R., Flagan, R. C., and Seinfeld, J. H.: Elemental composition and oxidation of chamber organic aerosol, Atmos. Chem. Phys., 11, 8827-8845, doi:10.5194/acp-11-88272011, 2011.

Cocker III, D. R., Flagan, R. C., and Seinfeld, J. H.: State-of-theart chamber facility for studying atmospheric aerosol chemistry, Environ. Sci. Technol., 35, 2594-2601, doi:10.1021/es0019169, 2001.

Correa, S. M. and Arbilla, G.: Aromatic hydrocarbons emissions in diesel and biodiesel exhaust, Atmos. Environ., 40, 6821-6826, doi:10.1016/j.atmosenv.2006.05.068, 2006.

Cross, E. S., Slowik, J. G., Davidovits, P., Allan, J. D., Worsnop, D. R., Jayne, J. T., Lewis, D. K., Canagaratna, M., and Onasch, T. B.: Laboratory and ambient particle density determinations using light scattering in conjunction with aerosol mass spectrometry, Aerosol Sci. Tech., 41, 343-359, doi:10.1080/02786820701199736, 2007.

Davidson, C. I., Phalen, R. F., and Solomon, P. A.: Airborne particulate matter and human health: A review, Aerosol Sci. Tech., 39, 737-749, doi:10.1080/02786820500191348, 2005.

DeCarlo, P. F., Slowik, J. G., Worsnop, D. R., Davidovits, P., and Jimenez, J. L.: Particle morphology and density characterization by combined mobility and aerodynamic diameter measurements, Part 1: Theory, Aerosol Sci. Tech., 38, 1185-1205, doi:10.1080/027868290903907, 2004.

DeCarlo, P. F., Kimmel, J. R., Trimborn, A., Northway, M. J., Jayne, J. T., Aiken, A. C., Gonin, M., Fuhrer, K., Horvath, T., Docherty, K. S., Worsnop, D. R., and Jimenez, J. L.: Field-deployable, high-resolution, time-of-flight aerosol mass spectrometer, Anal. Chem., 78, 8281-8289, doi:10.1021/ac061249n, 2006.

Derwent, R. G., Jenkin, M. E., Utembe, S. R., Shallcross, D. E., Murrells, T. P., and Passant, N. R.: Secondary organic aerosol formation from a large number of reactive man-made organic compounds, Sci. Total. Environ., 408, 3374-3381, doi:10.1016/j.scitotenv.2010.04.013, 2010.

Dinar, E., Mentel, T. F., and Rudich, Y.: The density of humic acids and humic like substances (HULIS) from fresh and aged wood burning and pollution aerosol particles, Atmos. Chem. Phys., 6, 5213-5224, doi:10.5194/acp-6-5213-2006, 2006.

Dockery, D. W., Pope, C. A., Xu, X., Spengler, J. D., Ware, J. H., Fay, M. E., Ferris Jr., B. G., and Speizer, F. E.: An association between air pollution and mortality in six US cities, New. Engl. J. Med., 329, 1753-1759, doi:10.1056/NEJM199312093292401, 1993.

Duplissy, J., DeCarlo, P. F., Dommen, J., Alfarra, M. R., Metzger, A., Barmpadimos, I., Prevot, A. S. H., Weingartner, E., Tritscher, T., Gysel, M., Aiken, A. C., Jimenez, J. L., Canagaratna, M. R., Worsnop, D. R., Collins, D. R., Tomlinson, J., and Baltensperger, U.: Relating hygroscopicity and composition of organic aerosol particulate matter, Atmos. Chem. Phys., 11, 11551165, doi:10.5194/acp-11-1155-2011, 2011.

Eddingsaas, N. C., Loza, C. L., Yee, L. D., Chan, M., Schilling, K. A., Chhabra, P. S., Seinfeld, J. H., and Wennberg, P. O.: $\alpha$-pinene photooxidation under controlled chemical conditions - Part 2: SOA yield and composition in low- and high- $\mathrm{NO}_{x}$ environments, 
Atmos. Chem. Phys., 12, 7413-7427, doi:10.5194/acp-12-74132012, 2012

Farina, S. C., Adams, P. J., and Pandis, S. N.: Modeling global secondary organic aerosol formation and processing with the volatility basis set: Implications for anthropogenic secondary organic aerosol, J. Geophys. Res.-Atmos., 115, D09202, doi:10.1029/2009JD013046, 2010.

Fisseha, R., Dommen, J., Sax, M., Paulsen, D., Kalberer, M., Maurer, R., Höfler, F., Weingartner, E., and Baltensperger, U.: Identification of organic acids in secondary organic aerosol and the corresponding gas phase from chamber experiments, Anal. Chem., 76, 6535-6540, doi:10.1021/ac048975f, 2004.

Forstner, H. J. L., Flagan, R. C., and Seinfeld, J. H.: Secondary organic aerosol from the photooxidation of aromatic hydrocarbons: Molecular composition, Environ. Sci. Technol., 31, 1345-1358, doi:10.1021/es9605376, 1997.

Hallquist, M., Wenger, J. C., Baltensperger, U., Rudich, Y., Simpson, D., Claeys, M., Dommen, J., Donahue, N. M., George, C., Goldstein, A. H., Hamilton, J. F., Herrmann, H., Hoffmann, T., Iinuma, Y., Jang, M., Jenkin, M. E., Jimenez, J. L., Kiendler-Scharr, A., Maenhaut, W., McFiggans, G., Mentel, Th. F., Monod, A., Prévôt, A. S. H., Seinfeld, J. H., Surratt, J. D., Szmigielski, R., and Wildt, J.: The formation, properties and impact of secondary organic aerosol: current and emerging issues, Atmos. Chem. Phys., 9, 5155-5236, doi:10.5194/acp-9-51552009, 2009.

Hamilton, J. F., Webb, P. J., Lewis, A. C., and Reviejo, M. M.: Quantifying small molecules in secondary organic aerosol formed during the photo-oxidation of toluene with hydroxyl radicals, Atmos. Environ., 39, 7263-7275, doi:10.1016/j.atmosenv.2005.09.006, 2005.

Heald, C. L., Goldstein, A. H., Allan, J. D., Aiken, A. C., Apel, E., Atlas, E. L., Baker, A. K., Bates, T. S., Beyersdorf, A. J., Blake, D. R., Campos, T., Coe, H., Crounse, J. D., DeCarlo, P. F., de Gouw, J. A., Dunlea, E. J., Flocke, F. M., Fried, A., Goldan, P., Griffin, R. J., Herndon, S. C., Holloway, J. S., Holzinger, R., Jimenez, J. L., Junkermann, W., Kuster, W. C., Lewis, A. C., Meinardi, S., Millet, D. B., Onasch, T., Polidori, A., Quinn, P. K., Riemer, D. D., Roberts, J. M., Salcedo, D., Sive, B., Swanson, A. L., Talbot, R., Warneke, C., Weber, R. J., Weibring, P., Wennberg, P. O., Worsnop, D. R., Wittig, A. E., Zhang, R., Zheng, J., and Zheng, W.: Total observed organic carbon (TOOC) in the atmosphere: a synthesis of North American observations, Atmos. Chem. Phys., 8, 2007-2025, doi:10.5194/acp-8-20072008, 2008.

Heald, C. L., Kroll, J. H., Jimenez, J. L., Docherty, K. S., DeCarlo, P. F., Aiken, A. C., Chen, Q., Martin, S. T., Farmer, D. K., and Artaxo, P.: A simplified description of the evolution of organic aerosol composition in the atmosphere, Geophys. Res. Lett, 37, L08803, doi:10.1029/2010GL042737, 2010.

Henze, D. K., Seinfeld, J. H., Ng, N. L., Kroll, J. H., Fu, T.-M., Jacob, D. J., and Heald, C. L.: Global modeling of secondary organic aerosol formation from aromatic hydrocarbons: highvs. low-yield pathways, Atmos. Chem. Phys., 8, 2405-2420, doi:10.5194/acp-8-2405-2008, 2008.

Hu, L., Millet, D. B., Baasandorj, M., Griffis, T. J., Travis, K. R., Tessum, C. W., Marshall, J. D., Reinhart, W. F., Mikoviny, T., Müller, M., Wisthaler, A., Graus, M., Warneke, C., and de Gouw, J.: Emissions of $\mathrm{C}_{6}-\mathrm{C}_{8}$ aromatic com- pounds in the United States: Constraints from tall tower and aircraft measurements, J. Geophys. Res.-Atmos., 120, 826-842, doi:10.1002/2014JD022627, 2015.

Huang, M., Zhang, W., Hao, L., Wang, Z., Zhao, W., Gu, X., Guo, X., Liu, X., Long, B., and Fang, L.: Laser desorption/ionization mass spectrometric study of secondary organic aerosol formed from the photooxidation of aromatics, J. Atmos. Chem., 58, 237252, doi:10.1007/s10874-007-9090-x, 2007.

Huang, M., Wang, Z., Hao, L., and Zhang, W.: Theoretical investigation on the mechanism and kinetics of $\mathrm{OH}$ radical with ethylbenzene, Int. J. Quantum. Chem., 111, 3125-3134, doi:10.1002/qua.22751, 2011.

IPCC: Intergovernmental Panel on Climate Change: Climate Change 2007: The Physical Science Basis, Cambridge University Press, Cambridge, UK, 6, 07, 2007.

Izumi, K. and Fukuyama, T. : Photochemical aerosol formation from aromatic hydrocarbons in the presence of $\mathrm{NO}_{x}$, Atmos. Environ. A-Gen., 24, 1433-1441, doi:10.1016/09601686(90)90052-O, 1990.

Jang, M., Czoschke, N. M., Lee, S., and Kamens, R. M.: Heterogeneous atmospheric aerosol production by acidcatalyzed particle-phase reactions, Science, 298, 814-817, doi:10.1126/science.1075798, 2002.

Jimenez, J. L., Canagaratna, M. R., Donahue, N. M., Prevot, A. S. H., Zhang, Q., Kroll, J. H., DeCarlo, P. F., Allan, J. D., Coe, H., Ng, N. L., Aiken, A. C., Docherty, K. S., Ulbrich, I. M., Grieshop, A. P., Robinson, A. L., Duplissy, J., Smith, J. D., Wilson, K. R., Lanz, V. A., Hueglin, C., Sun, Y. L., Tian, J., Laaksonen, A., Raatikainen, T., Rautiainen, J., Vaattovaara, P., Ehn, M., Kulmala, M., Tomlinson, J. M., Collins, D. R., Cubison, M. J., Dunlea, E., J., Huffman, J. A., Onasch, T. B., Alfarra, M. R., Williams, P. I., Bower, K., Kondo, Y., Schneider, J., Drewnick, F., Borrmann, S., Weimer, S.,, Demerjian, K., Salcedo, D., Cottrell, L., Griffin, R., Takami, A., Miyoshi, T., Hatakeyama, S., Shimono, A., Sun, J. Y., Zhang, Y. M., Dzepina, K., Kimmel, J. R., Sueper, D., J. Jayne, T., Herndon, S. C., Trimborn, A. M., Williams, L. R., Wood, E. C., Middlebrook, A. M., Kolb, C. E., Baltensperger, U., and Worsnop D. R.: Evolution of organic aerosols in the atmosphere, Science, 326, 1525-1529, doi:10.1126/science.1180353, 2009.

Kaiser, E. W., Siegl, W. O., Cotton, D. F., and Anderson, R. W.: Effect of fuel structure on emissions from a spark-ignited engine. 2. Naphthene and aromatic fuels, Environ. Sci. Technol., 26, 1581-1586, doi:10.1021/es00032a014, 1992.

Kalberer, M., Paulsen, D., Sax, M., Steinbacher, M., Dommen, J., Prevot, A. S. H., Fisseha, R., Weingartner, E., Frankevich, V., and Zenobi, R.: Identification of polymers as major components of atmospheric organic aerosols, Science, 303, 1659-1662, doi:10.1126/science.1092185, 2004.

Kanakidou, M., Seinfeld, J. H., Pandis, S. N., Barnes, I., Dentener, F. J., Facchini, M. C., Van Dingenen, R., Ervens, B., Nenes, A., Nielsen, C. J., Swietlicki, E., Putaud, J. P., Balkanski, Y., Fuzzi, S., Horth, J., Moortgat, G. K., Winterhalter, R., Myhre, C. E. L., Tsigaridis, K., Vignati, E., Stephanou, E. G., and Wilson, J.: Organic aerosol and global climate modelling: a review, Atmos. Chem. Phys., 5, 1053-1123, doi:10.5194/acp-5-1053-2005, 2005. 
Kansal, A.: Sources and reactivity of NMHCs and VOCs in the atmosphere: a review, J. Hazard. Mater., 166, 17-26, doi:10.1016/j.jhazmat.2008.11.048, 2009.

Katrib, Y., Martin, S. T., Rudich, Y., Davidovits, P., Jayne, J. T., and Worsnop, D. R.: Density changes of aerosol particles as a result of chemical reaction, Atmos. Chem. Phys., 5, 275-291, doi:10.5194/acp-5-275-2005, 2005.

Krewski, D., Burnett, R., Goldberg, M., Hoover, B. K., Siemiatycki, J., Jerrett, M., Abrahamowicz, M., and White, W.: Overview of the reanalysis of the Harvard six cities study and American Cancer Society study of particulate air pollution and mortality, J. Toxicol. Env. Heal. A, 66, 1507-1552, doi:10.1080/15287390306424, 2003.

Kroll, J. H., Donahue, N. M., Jimenez, J. L., Kessler, S. H., Canagaratna, M. R., Wilson, K. R., Altieri, K. E., Mazzoleni, L. R., Wozniak, A. S., Bluhm, H., Mysak, E. R., Smith, J. D., Kolb, C. E., and Worsnop D. R.: Carbon oxidation state as a metric for describing the chemistry of atmospheric organic aerosol, Nature Chemistry, 3, 133-139, doi:10.1038/nchem.948, 2011.

Kuwata, M., Zorn, S. R., and Martin, S. T.: Using elemental ratios to predict the density of organic material composed of carbon, hydrogen, and oxygen, Environ. Sci. Technol., 46, 787-794, doi:10.1021/es202525q, 2011.

Lal, V., Khalizov, A. F., Lin, Y., Galvan, M. D., Connell, B. T., and Zhang, R.: Heterogeneous reactions of epoxides in acidic media, J. Phys. Chem. A., 116, 6078-6090, doi:10.1021/jp2112704, 2012.

Lambe, A. T., Onasch, T. B., Croasdale, D. R., Wright, J. P., Martin, A. T., Franklin, J. P., Massoli, P., Kroll, J. H., Canagaratna, M. R., Brune, W. H., Worsnop, D. R., and Davidovits P.: Transitions from functionalization to fragmentation reactions of laboratory secondary organic aerosol (SOA) generated from the $\mathrm{OH}$ oxidation of alkane precursors, Environ. Sci. Technol., 46, 5430-5437, doi:10.1021/es300274t, 2012.

Lambe, A. T., Chhabra, P. S., Onasch, T. B., Brune, W. H., Hunter, J. F., Kroll, J. H., Cummings, M. J., Brogan, J. F., Parmar, Y., Worsnop, D. R., Kolb, C. E., and Davidovits, P.: Effect of oxidant concentration, exposure time, and seed particles on secondary organic aerosol chemical composition and yield, Atmos. Chem. Phys., 15, 3063-3075, doi:10.5194/acp-15-3063-2015, 2015.

Li, L., Tang, P., and Cocker III, D. R.: Instantaneous nitric oxide effect on secondary organic aerosol formation from $m$-xylene photooxidation, Atmos. Environ., 119, 144-155, doi:10.1016/j.atmosenv.2015.08.010, 2015.

Li, L., Tang, P., Nakao, S., Chen, C.-L., and Cocker III, D. R.: Role of methyl group number on SOA formation from monocyclic aromatic hydrocarbons photooxidation under low- $\mathrm{NO}_{x}$ conditions, Atmos. Chem. Phys., 16, 2255-2272, doi:10.5194/acp-162255-2016, 2016.

Liggio, J., Li, S.-M., and McLaren R.: Heterogeneous reactions of glyoxal on particulate matter: Identification of acetals and sulfate esters, Environ. Sci. Technol., 39, 1532-1541, doi:10.1021/es048375y, 2005.

Lim, Y. B. and Ziemann, P. J.: Effects of molecular structure on aerosol yields from $\mathrm{OH}$ radical-initiated reactions of linear, branched, and cyclic alkanes in the presence of $\mathrm{NO}_{x}$, Environ. Sci. Technol., 43, 2328-2334, doi:10.1021/es803389s, 2009.

Lough, G. C., Schauer, J. J., Lonneman, W. A., and Allen, M. K.: Summer and winter nonmethane hydrocarbon emissions from on-road motor vehicles in the Midwestern United States, J. Air Waste Manage., 55, 629-646, doi:10.1080/10473289.2005.10464649, 2005.

Loza, C. L., Chhabra, P. S., Yee, L. D., Craven, J. S., Flagan, R. C., and Seinfeld, J. H.: Chemical aging of $m$-xylene secondary organic aerosol: laboratory chamber study, Atmos. Chem. Phys., 12, 151-167, doi:10.5194/acp-12-151-2012, 2012.

Loza, C. L., Craven, J. S., Yee, L. D., Coggon, M. M., Schwantes, R. H., Shiraiwa, M., Zhang, X., Schilling, K. A., Ng, N. L., Canagaratna, M. R., Ziemann, P. J., Flagan, R. C., and Seinfeld, J. H.: Secondary organic aerosol yields of 12-carbon alkanes, Atmos. Chem. Phys., 14, 1423-1439, doi:10.5194/acp-14-14232014, 2014.

Malloy, Q. G., Nakao, S., Qi, L., Austin, R., Stothers, C., Hagino, H., and Cocker III, D. R.: Real-Time Aerosol Density Determination Utilizing a Modified Scanning Mobility Particle Sizer Aerosol Particle Mass Analyzer System, Aerosol. Sci. Tech., 43, 673-678, doi:10.1080/02786820902832960, 2009.

Matsui, H., Koike, M., Takegawa, N., Kondo, Y., Griffin, R., Miyazaki, Y., Yokouchi, Y., and Ohara, T.: Secondary organic aerosol formation in urban air: Temporal variations and possible contributions from unidentified hydrocarbons, J. Geophys. Res.Atmos, 114, D04201, doi:10.1029/2008JD010164, 2009.

McLafferty, F. W. and Turecek, F.: Interpretation of mass spectra, University Science Books, Mill Valley, California, USA, 1993.

Millet, D. B., Donahue, N. M., Pandis, S. N., Polidori, A., Stanier, C. O., Turpin, B. J., and Goldstein, A. H.: Atmospheric volatile organic compound measurements during the Pittsburgh Air Quality Study: Results, interpretation, and quantification of primary and secondary contributions, J. Geophys. Res.-Atmos, 110, D07S07, doi:10.1029/2004JD004601, 2005.

Minerath, E. C. and Elrod, M. J.: Assessing the potential for diol and hydroxy sulfate ester formation from the reaction of epoxides in tropospheric aerosols, Environ. Sci. Technol., 43, 1386-1392, doi:10.1021/es8029076, 2009.

Miracolo, M. A., Drozd, G. T., Jathar, S. H., Presto, A. A., Lipsky, E. M., Corporan, E., and Robinson, A.L.: Fuel composition and secondary organic aerosol formation: Gas-turbine exhaust and alternative aviation fuels, Environ. Sci. Technol., 46, 8493-8501, doi:10.1021/es300350c, 2012.

Monod, A., Sive, B. C., Avino, P., Chen, T., Blake, D. R., and Rowland, F. S.: Monoaromatic compounds in ambient air of various cities: a focus on correlations between the xylenes and ethylbenzene, Atmos. Environ., 35, 135-149, doi:10.1016/S13522310(00)00274-0, 2001.

Na, K., Moon, K.-C., and Kim, Y. P.: Source contribution to aromatic VOC concentration and ozone formation potential in the atmosphere of Seoul, Atmos. Environ., 39, 5517-5524, doi:10.1016/j.atmosenv.2005.06.005, 2005.

Nakao, S., Clark, C., Tang, P., Sato, K., and Cocker III, D.: Secondary organic aerosol formation from phenolic compounds in the absence of $\mathrm{NO}_{x}$, Atmos. Chem. Phys., 11, 10649-10660, doi:10.5194/acp-11-10649-2011, 2011.

Nakao, S., Liu, Y., Tang, P., Chen, C.-L., Zhang, J., and Cocker III, D. R.: Chamber studies of SOA formation from aromatic hydrocarbons: observation of limited glyoxal uptake, Atmos. Chem. Phys., 12, 3927-3937, doi:10.5194/acp-12-3927-2012, 2012.

Ng, N. L., Kroll, J. H., Chan, A. W. H., Chhabra, P. S., Flagan, R. C., and Seinfeld, J. H.: Secondary organic aerosol formation 
from $m$-xylene, toluene, and benzene, Atmos. Chem. Phys., 7, 3909-3922, doi:10.5194/acp-7-3909-2007, 2007.

Ng, N. L., Canagaratna, M. R., Zhang, Q., Jimenez, J. L., Tian, J., Ulbrich, I. M., Kroll, J. H., Docherty, K. S., Chhabra, P. S., Bahreini, R., Murphy, S. M., Seinfeld, J. H., Hildebrandt, L., Donahue, N. M., DeCarlo, P. F., Lanz, V. A., Prévôt, A. S. H., Dinar, E., Rudich, Y., and Worsnop, D. R.: Organic aerosol components observed in Northern Hemispheric datasets from Aerosol Mass Spectrometry, Atmos. Chem. Phys., 10, 46254641, doi:10.5194/acp-10-4625-2010, 2010.

Ng, N. L., Canagaratna, M. R., Jimenez, J. L., Chhabra, P. S., Seinfeld, J. H., and Worsnop, D. R.: Changes in organic aerosol composition with aging inferred from aerosol mass spectra, Atmos. Chem. Phys., 11, 6465-6474, doi:10.5194/acp-11-64652011, 2011.

Odum, J. R., Hoffmann, T., Bowman, F., Collins, D., Flagan, R. C., and Seinfeld, J. H.: Gas/particle partitioning and secondary organic aerosol yields, Environ. Sci. Technol., 30, 2580-2585, doi:10.1021/es950943+, 1996.

Odum, J. R., Jungkamp, T., Griffin, R., Flagan, R. C., and Seinfeld, J. H.: The atmospheric aerosol-forming potential of whole gasoline vapor, Science, 276, 96-99, doi:10.1126/science.276.5309.96, 1997a.

Odum, J. R., Jungkamp, T., Griffin, R. J., Forstner, H., Flagan, R. C., and Seinfeld, J. H.: Aromatics, reformulated gasoline, and atmospheric organic aerosol formation, Environ. Sci. Technol., 31, 1890-1897, doi:10.1021/es9605351, 1997 b.

Pang, Y., Turpin, B., and Gundel, L.: On the importance of organic oxygen for understanding organic aerosol particles, Aerosol. Sci. Tech., 40, 128-133, doi:10.1080/02786820500423790, 2006.

Pfaffenberger, L., Barmet, P., Slowik, J. G., Praplan, A. P., Dommen, J., Prévôt, A. S. H., and Baltensperger, U.: The link between organic aerosol mass loading and degree of oxygenation: an apinene photooxidation study, Atmos. Chem. Phys., 13, 64936506, doi:10.5194/acp-13-6493-2013, 2013.

Pöschl, U.: Atmospheric aerosols: Composition, transformation, climate and health effects, Angew. Chem. Int. Edit., 44, 7520 7540, 10.1002/anie.200501122, 2005.

Qi, L., Nakao, S., Malloy, Q., Warren, B., and Cocker III, D. R.: Can secondary organic aerosol formed in an atmospheric simulation chamber continuously age?, Atmos. Environ., 44, 29902996, doi:10.1016/j.atmosenv.2010.05.020, 2010a.

Qi, L., Nakao, S., Tang, P., and Cocker III, D. R.: Temperature effect on physical and chemical properties of secondary organic aerosol from $m$-xylene photooxidation, Atmos. Chem. Phys., 10, 38473854, doi:10.5194/acp-10-3847-2010, 2010 b.

Rader, D. J. and McMurry, P. H.: Application of the tandem differential mobility analyzer to studies of droplet growth or evaporation, J. Aerosol. Sci., 17, 771-787, doi:10.1016/00218502(86)90031-5, 1986.

Rubin, J. I., Kean, A. J., Harley, R. A., Millet, D. B., and Goldstein, A. H.: Temperature dependence of volatile organic compound evaporative emissions from motor vehicles, J. Geophys. Res.-Atmos, 111, D03305, doi:10.1029/2005JD006458, 2006.

Salo, K., Hallquist, M., Jonsson, Å. M., Saathoff, H., Naumann, K.H., Spindler, C., Tillmann, R., Fuchs, H., Bohn, B., Rubach, F., Mentel, Th. F., Müller, L., Reinnig, M., Hoffmann, T., and Donahue, N. M.: Volatility of secondary organic aerosol during $\mathrm{OH}$ radical induced ageing, Atmos. Chem. Phys., 11, 11055-11067, doi:10.5194/acp-11-11055-2011, 2011.

Sato, K., Hatakeyama, S., and Imamura, T.: Secondary organic aerosol formation during the photooxidation of toluene: $\mathrm{NO}_{x}$ dependence of chemical composition, J. Phys. Chem. A., 111, 9796-9808, doi:10.1021/jp071419f, 2007.

Sato, K., Takami, A., Isozaki, T., Hikida, T., Shimono, A., and Imamura, T.: Mass spectrometric study of secondary organic aerosol formed from the photo-oxidation of aromatic hydrocarbons, Atmos. Environ., 44, 1080-1087, doi:10.1016/j.atmosenv.2009.12.013, 2010.

Sato, K., Takami, A., Kato, Y., Seta, T., Fujitani, Y., Hikida, T., Shimono, A., and Imamura, T.: AMS and LC/MS analyses of SOA from the photooxidation of benzene and 1,3,5-trimethylbenzene in the presence of $\mathrm{NO}_{x}$ : effects of chemical structure on SOA aging, Atmos. Chem. Phys., 12, 4667-4682, doi:10.5194/acp-124667-2012, 2012.

Seinfeld, J. and Pandis, S.: Atmospheric chemistry and physics: from air pollution to climate change, John Wiley \& Sons Publications, Hoboken, New Jersey, USA, 2006.

Shilling, J. E., Chen, Q., King, S. M., Rosenoern, T., Kroll, J. H., Worsnop, D. R., DeCarlo, P. F., Aiken, A. C., Sueper, D., Jimenez, J. L., and Martin, S. T.: Loading-dependent elemental composition of $\alpha$-pinene SOA particles, Atmos. Chem. Phys., 9, 771-782, doi:10.5194/acp-9-771-2009, 2009.

Singh, H. B., Salas, L. J., Cantrell, B. K., and Redmond, R. M.: Distribution of aromatic hydrocarbons in the ambient air, Atmos. Environ., 19, 1911-1919, doi:10.1016/0004-6981(85)90017-4, 1985.

Song, C., Na, K., and Cocker III, D. R.: Impact of the hydrocarbon to $\mathrm{NO}_{x}$ ratio on secondary organic aerosol formation, Environ. Sci. Technol., 39, 3143-3149, doi:10.1021/es0493244, 2005.

Song, C., Na, K., Warren, B., Malloy, Q., and Cocker III, D. R.: Secondary organic aerosol formation from the photooxidation of $p$-and $o$-xylene. Environ. Sci. Technol., 41, 7403-7408, doi:10.1021/es0621041, 2007.

Tkacik, D. S., Presto, A. A., Donahue, N. M., and Robinson, A. L.: Secondary organic aerosol formation from intermediate-volatility organic compounds: cyclic, linear, and branched alkanes, Environ. Sci. Technol., 46, 8773-8781, doi:10.1021/es301112c, 2012.

Tritscher, T., Dommen, J., DeCarlo, P. F., Gysel, M., Barmet, P. B., Praplan, A. P., Weingartner, E., Prévôt, A. S. H., Riipinen, I., Donahue, N. M., and Baltensperger, U.: Volatility and hygroscopicity of aging secondary organic aerosol in a smog chamber, Atmos. Chem. Phys., 11, 11477-11496, doi:10.5194/acp-1111477-2011, 2011.

Yee, L. D., Kautzman, K. E., Loza, C. L., Schilling, K. A., Coggon, M. M., Chhabra, P. S., Chan, M. N., Chan, A. W. H., Hersey, S. P., Crounse, J. D., Wennberg, P. O., Flagan, R. C., and Seinfeld, J. H.: Secondary organic aerosol formation from biomass burning intermediates: phenol and methoxyphenols, Atmos. Chem. Phys., 13, 8019-8043, doi:10.5194/acp-13-8019-2013, 2013.

Yu, L., Smith, J., Laskin, A., Anastasio, C., Laskin, J., and Zhang, Q.: Chemical characterization of SOA formed from aqueousphase reactions of phenols with the triplet excited state of carbonyl and hydroxyl radical, Atmos. Chem. Phys., 14, 1380113816, doi:10.5194/acp-14-13801-2014, 2014. 
Zhang, Q., Alfarra, M. R., Worsnop, D. R., Allan, J. D., Coe, H., Canagaratna, M. R., and Jimenez, J. L.: Deconvolution and quantification of hydrocarbon-like and oxygenated organic aerosols based on aerosol mass spectrometry, Environ. Sci. Technol., 39, 4938-4952, doi:10.1021/es0485681, 2005.

Zhang, Y., Wang, X., Barletta, B., Simpson, I. J., Blake, D. R., Fu, X., Zhang, Z., He, Q., Liu, T., Zhao, X., and Ding, X.: Source attributions of hazardous aromatic hydrocarbons in urban, suburban and rural areas in the Pearl River Delta (PRD) region, J. Hazard. Mater., 250, 403-411, doi:10.1016/j.jhazmat.2013.02.023, 2013.

Zhou, Y., Zhang, H., Parikh, H. M., Chen, E. H., Rattanavaraha, W., Rosen, E. P., Wang, W., and Kamens, R. M.: Secondary organic aerosol formation from xylenes and mixtures of toluene and xylenes in an atmospheric urban hydrocarbon mixture: water and particle seed effects (II), Atmos. Environ., 45, 3882-3890, doi:10.1016/j.atmosenv.2010.12.048, 2011.
Ziemann, P.: Effects of molecular structure on the chemistry of aerosol formation from the OH-radical-initiated oxidation of alkanes and alkenes, Int. Rev. Phys. Chem., 30, 161-195, doi:10.1080/0144235X.2010.550728, 2011.

Ziemann, P. J. and Atkinson, R.: Kinetics, products, and mechanisms of secondary organic aerosol formation, Chem. Soc. Rev., 41, 6582-6605, doi:10.1039/c2cs35122f, 2012. 